TI 2019-005/VIII

Tinbergen Institute Discussion Paper
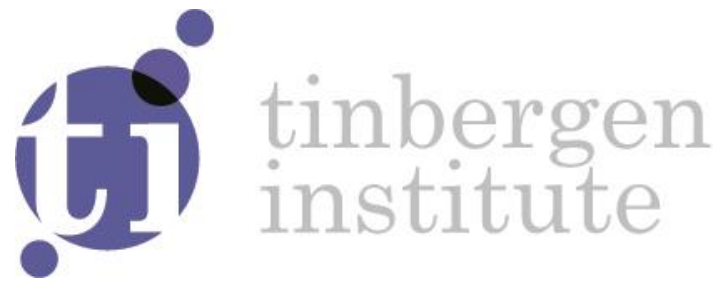

\title{
Autonomous, Connected, Electric Shared vehicles (ACES) and public finance: an explorative analysis
}

Martin Adler ${ }^{1}$

Stefanie Peer ${ }^{2}$

Tanja Sinozic ${ }^{3}$

${ }^{1}$ VU University Amsterdam; Tinbergen PhD student; AtAdlerAdvisory, The Netherlands

2 Vienna University of Economics and Business, Austria

${ }^{3}$ Institute of Technology Assessment (ITA), Austrian Academy of Sciences (OEAW) 
Tinbergen Institute is the graduate school and research institute in economics of Erasmus University Rotterdam, the University of Amsterdam and VU University Amsterdam.

Contact: discussionpapers@tinbergen.nl

More TI discussion papers can be downloaded at http://www.tinbergen.nl

Tinbergen Institute has two locations:

Tinbergen Institute Amsterdam

Gustav Mahlerplein 117

1082 MS Amsterdam

The Netherlands

Tel.: +31(0)205984580

Tinbergen Institute Rotterdam

Burg. Oudlaan 50

3062 PA Rotterdam

The Netherlands

Tel.: +31(0)10408 8900 


\section{Autonomous, Connected, Electric Shared vehicles (ACES) and public finance: an explorative analysis}

Adler, M. W., Peer, S., Sinozic, T. $^{1}$

November 2018

Abstract

This paper discusses the implications of autonomous-connected-electric-shared vehicles (ACES) for public finance, which have so far been widely ignored. In OECD countries, 5-12\% of federal and up to $30 \%$ of local tax revenue are currently from fuel and vehicle taxation. The diffusion of ACES will likely reduce these important sources of government revenues, while also affecting transport-related government expenditures. We argue that the realization of socioeconomic benefits of ACES depends on the implementation of tailored public finance policies. In particular, the introduction of road tolls in line with 'user pays' and 'polluter pays' principles will become more attractive. Moreover, innovation in taxation schemes to fit the changing technological circumstances may alter the (relative) importance of levels of governance in transport policy making, likely shifting power towards local (in particular urban) governmental levels. We finally argue that due to path-dependencies, and the risk of lock-in effects in sub-optimal public finance regimes, further research and near-term policy action regarding ACES is required.

Keywords: autonomous connected electric shared vehicles; public finance; taxation; fiscal revenues; fiscal expenditures; disruptive technologies; path-dependency; technological transition; political economy; multilevelgovernance

\footnotetext{
${ }^{1}$ Martin Adler (m.w.adler@vu.nl) is a researcher at VU Amsterdam and the Tinbergen Institute, consultant at AtAdlerAdvisory, and Policy Fellow at Policy Network. Stefanie Peer (stefanie.peer@wu.ac.at) is Assistant Professor at the Vienna University of Economics and Business. She gratefully acknowledges funding from the Austrian Climate Research Program (ACRP) for the project "SimSAEV". Tanja Sinozic (tanja.sinozic@oeaw.ac.at) is senior researcher at the Institute of Technology Assessment (ITA), Austrian Academy of Sciences (OEAW). The authors would like to thank the participants of the Summer Conference (2017) as well as of the Winter Seminar (2018) of the German-speaking section of the European Regional Science Association, participants of the European Parliamentary Technology Assessment Conference (EPTA) 2017, the seminar participants at the Masaryk University Brno (2018), the 2018 WIFO Regional Economics Workshop participants, as well as Antonio Russo and Carl Koopmans for their valuable feedback.
} 


\section{Introduction}

Disruptive technologies can, by definition, have substantial effects on broad aspects of public policy. Changes in public finance expenditures and revenues are particularly pertinent as these technologies might require large-scale public investments in infrastructure, education and training. At the same time, previously taxed technologies and products can become obsolete, which may lead to a shortfall of tax revenues, and to path-dependencies which in turn may create lock-in effects in suboptimal taxation regimes. Due to their effects on labor markets and productivity, disruptive technologies also tend to affect (private and corporate) income tax revenues as well as social welfare spending. Nevertheless, the impact of technological change on (optimal) public finance has not been widely researched. The topic has, however, recently gained interest in the context of the (optimal) taxation of robots (e.g., Guerreiro, 2017; Thuemmel, 2018).

This paper discusses the case of autonomous connected electric vehicles (ACES), which are the result of four major ongoing developments in transportation: (1) automation (automated vehicles: AVs), (2) connectivity and digitalization (connected vehicles or CVs), (3) electrification (electric vehicles: EVs), and (4) shared ownership (shared vehicles: SVs). These technologies (separately, but especially in their combination) are expected to lead to major disruptions in the transport market, which has been in a fairly stable technological regime over the past decades (Pinkse et al., 2014; Dijk et al., 2016). Although the pace and shape of the disruptive changes induced by ACES cannot be predicted accurately at this point in time, there seems to be a consensus in the relevant literature that after 2040 most vehicles in the developed world will be electric and capable of autonomous driving, with connectivity being an essential prerequisite for autonomous driving and shared ownership a logical consequence (see for instance Leech et al., 2015; Kaas et al., 2016; Ranft et al., 2016).

In this paper, we focus on the interrelationships between ACES and public finance. The interplay between ACES and public finance has so far been discussed only in a handful of policy papers (Clark et al., 2017; Peterson and Lewis, 2017; Mares et al., 2018) and newspaper articles (e.g. Fung, 2016), but has barely received any attention in academic research so far, although being recommended as a subject for further study by the European Commission Joint Research Center (Alonso Raposo et al., 2018, p.151). This article aims at closing this gap, by gathering and connecting information from multiple research streams in public finance, transport economics, urban economics, innovation and technology, energy and environmental economics. The paper discusses various hypotheses, sets up a research agenda, and provides first guidelines for public finance policies in the context of ACES. The topic is timely and important, as the technological developments enabling the introduction of ACES progress quickly albeit incrementally, and policy makers need to be prepared for the potential challenges resulting from the impacts of ACES on public finance. This is particularly true due to the path dependencies and potential lock-in effects in suboptimal fiscal regimes which have many precedents in the transport sector.

Currently, fuel and vehicle taxation generate approximately $5-12 \%$ of federal and up to $30 \%$ of local tax revenue in OECD countries. On the expenditure side, about $1-3 \%$ of national and up to $50 \%$ of regional budgets are assigned to land-based transport. The pending introduction of ACES is expected to have significant impacts, among others, on fuel consumption, travel demand, car ownership structure, public transport, infrastructure requirements, and the wider economy, and as a consequence also on fiscal revenues and expenditures. With an increasing electrification of the car fleet, revenues from fuel taxes will fall substantially (and tax rates on electricity are only a fraction of the former). If car- and ride-sharing are adopted widely, revenues from vehicle registration and circulation taxes may decline. Required investments in infrastructure (e.g. telecommunication and energy) and public transport may increase at least in the short and medium run but are likely to decrease in the long run. The impacts of ACES on the 
wider economy are expected to be positive, but the size of the impact and its fiscal ramifications are highly uncertain (see for instance Karpilow and Winston (2016) and Ranft et al. (2016) for estimates).

We argue that tailored public finance policies are essential to ensure that the benefits of ACES outweigh the corresponding costs and thereby help decrease uncertainty in this transition. If the transition towards ACES is not managed well at the policy level using an anticipatory approach, a loss of revenue from vehicle taxation and an increase in negative external costs can impact public finance and social welfare adversely. More specifically, we argue that the increased demand for mobility due to the availability of affordable and convenient ACES and the expected obsolescence of the currently common steering instruments in transport (fuel tax, parking charges) renders the introduction of targeted taxes in line with 'user pays' and 'polluter pays' principles necessary and feasible. We anticipate a shift in the importance of levels of governance: with targeted taxation schemes and declining federal tax revenues from fuel, registration and circulation taxes, local (in particular, urban) levels of governance are likely to gain a higher relevance in transport policy making. Moreover, we emphasize that path dependencies may lead to suboptimal taxation systems that are hard to re-adjust in the future, mainly due to a lack of public acceptance.

While the focus of this article lies on ACES employed for passenger transport with a capacity that can range from one-person-vehicles to vehicles that hold about a dozen persons (minibuses), many arguments can also be transferred to the freight sector and high-capacity passenger transport vehicles (such as trains, buses, and trams). Moreover, our main arguments also hold for vehicles that rely on other zero-emission technologies, powered for instance by hydrogen.

The paper is structured as follows. Chapter 2 provides an overview of current transport-related tax revenues and expenditures. Chapter 3 first gives an outlook on ACES, and proceeds with discussing likely fiscal effects of ACES, and the effect of ACES on transport-related externalities. Chapter 4 discusses our main hypotheses regarding public finance with respect to ACES and provides recommendations for future research. Finally, Chapter 5 concludes and makes concrete policy recommendations.

\section{Status-quo: vehicle-related tax revenues and expenditures}

This section discusses the status-quo of transport-related taxes and expenditures of selected OECD countries. The aim is to give an overview of vehicle-related public finance for the EU and the US citing official tax revenue and expenditure statistics, in order to provide a frame for the discussion of the potential fiscal implications of ACES. Despite efforts to make fiscal accounts related to vehicles comparable between countries, there is only limited, upto-date data available (Nash, 2003; Gomez and Vassallo, 2013; Link and Kunert, 2017).

\subsection{Revenues from vehicle-related taxes, fees and charges}

We can observe substantial differences with respect to vehicle taxation across countries; in terms of available tax instruments, their design and intended goals, and the level of governance at which specific tax revenues are collected. There are however some similarities across countries, especially with regards to the following three tax categories, which make up a large share of vehicle-related tax revenues in most countries, and that are usually levied at the federal level: 
(1) Gasoline taxes, including value-added-tax (VAT) and sales tax: Gasoline taxes exist in all OECD countries with the exception of Mexico, which only imposes a VAT. ${ }^{2}$ In the United States, some states levy an additional sales tax on gasoline purchases (Pomerleau, 2015). Often tax rates applied to gas and diesel differ: ${ }^{3}$ in the $\mathrm{EU}$, there is a tendency to base fuel taxation on the energy content of the fuel source and the contribution to $\mathrm{CO} 2$ pollution, whereas in the US, fuel taxes are intended to internalize road deterioration, and are hence referred to as "road use" taxes. Revenues from gasoline taxes are earmarked in some but not all European countries (European Commission, 2002) for transport purposes. ${ }^{4}$

(2) The registration taxes are usually a one-off tax that must be paid when a car, motorcycle or light goods vehicle is registered for the first time in a specific country. In some countries it also has to be levied on purchases of used cars. ${ }^{5}$ Usually the registration fee varies between car types and depends for instance on the purchase price, $\mathrm{CO} 2$ emissions/fuel efficiency, cylinder capacity, engine power, vehicle type, weight, fuel, traffic safety (e.g., Denmark), seats (e.g., Italy), vehicle length (e.g., Malta), and vehicle age. In some countries, electric vehicles are exempt from the registration tax (ACEA, 2017). In most countries, the registration tax is levied at the level of the national government, however, there are exceptions, such as France, Belgium, or the US. In the latter, they may even be city- or county-specific. In general, a value added $\operatorname{tax}$ (VAT) or sales tax is levied on top of the purchase price.

(3) The circulation (or vehicle ownership) tax is levied on cars registered for usage. It exists in most OECD countries; exceptions within the EU are Estonia, Lithuania, Poland, which do not levy any circulation tax. Its size and computation vary widely across countries. It often depends on factors such as engine power, cylinder capacity, $\mathrm{CO} 2$ emissions, fuel consumption, weight, or vehicle age. Similar to the registration tax, it is usually levied by the federal state, but in some countries, it is levied at lower governmental levels. For instance, in Belgium and Russia, it is in the responsibility of the regions. In several countries (e.g. the Netherlands), EVs are exempt from annual circulation taxes (ACEA, 2017).

Other relevant taxes and charges include road tolls, parking charges, taxes on company cars, insurance taxes, costs for periodical inspection (e.g. Belgium), traffic fines, local motoring taxes, and taxes for oil storage (Naess-Schmidt and Winiarczyk, 2009). ${ }^{6}$ The corresponding revenues are often earmarked which makes it easier for citizens to compare benefits and payments. ${ }^{7}$ Various studies (e.g. from Stockholm, London) show that acceptability of road pricing (and transport-related taxes in general) is higher if earmarked for transport system improvements (e.g. Oberholzer-Gee and Weck-Hannemann, 2002; Schuitema and Steg, 2008).

Vehicle-related taxes contribute a substantial share to fiscal revenues in all OECD countries. There is a noteworthy amount of cross-country heterogeneity in the types of taxes and the respective contribution of each tax to the budget (European Commission, 2002). See Figure 1 for a selected sample of European countries. Vehicle-related taxes are an important part in all national budgets as they exceed $5 \%$ of overall fiscal revenues and can sometimes be as high as ten percent (for instance, in the case of Portugal). As mentioned previously, the VAT on vehicle and vehicle part sales together with taxes on fuels and lubricants constitute the lion's share, amounting to over $60-80 \%$

\footnotetext{
2 OECD Tax database; http://www.oecd.org/tax/tax-policy/tax-database.htm\#VATTables, Table 4.A, 4.6 and Table 4.A4.7.

${ }^{3}$ See De Borger and Mayeres (2007) on the sub-optimality of lower Diesel tax rates in Belgium.

4 There are, however, some cases of partial earmarking of fuel tax revenues. This has been necessary in some countries, for instance as a justification for significant increases in fuel taxes, or as an easily recognisable instrument for stable financing of chronic-deficit public services like urban public transport.

${ }^{5}$ In several countries, the registration tax only applies to used vehicles if they are imported from abroad.

${ }^{6}$ In rare instances, traffic fines are the main source of local fiscal revenues. For example, in Mountain View, Colorado, $53 \%$ of the public budget is from tickets for traffic violations (Fung, 2016).

7 For instance, the Austrian tax on mineral oils was earmarked until 1987 for road construction, but since then just enters the general budget: https://www.oeamtc.at/thema/verkehr/mineraloelsteuer-17914742.
} 
of vehicle-related fiscal revenues. The remainder are a varying set of smaller contributions from annual ownership taxes and road tolls (as in the in case of Austria). Figure 1 shows that across countries, vehicle-related tax revenues mostly vary in their composition, while for a given country, both the tax composition and the relative contribution of vehicle-related taxes to overall fiscal revenues are fairly stable. As in Europe, also in the US, the primary source of fiscal revenues of vehicles are, fuel taxes collected at the federal and state level. These are usually earmarked for transport-related expenditures (Gomez and Vassallo, 2013).

Figure 1 - Fiscal revenues from vehicles

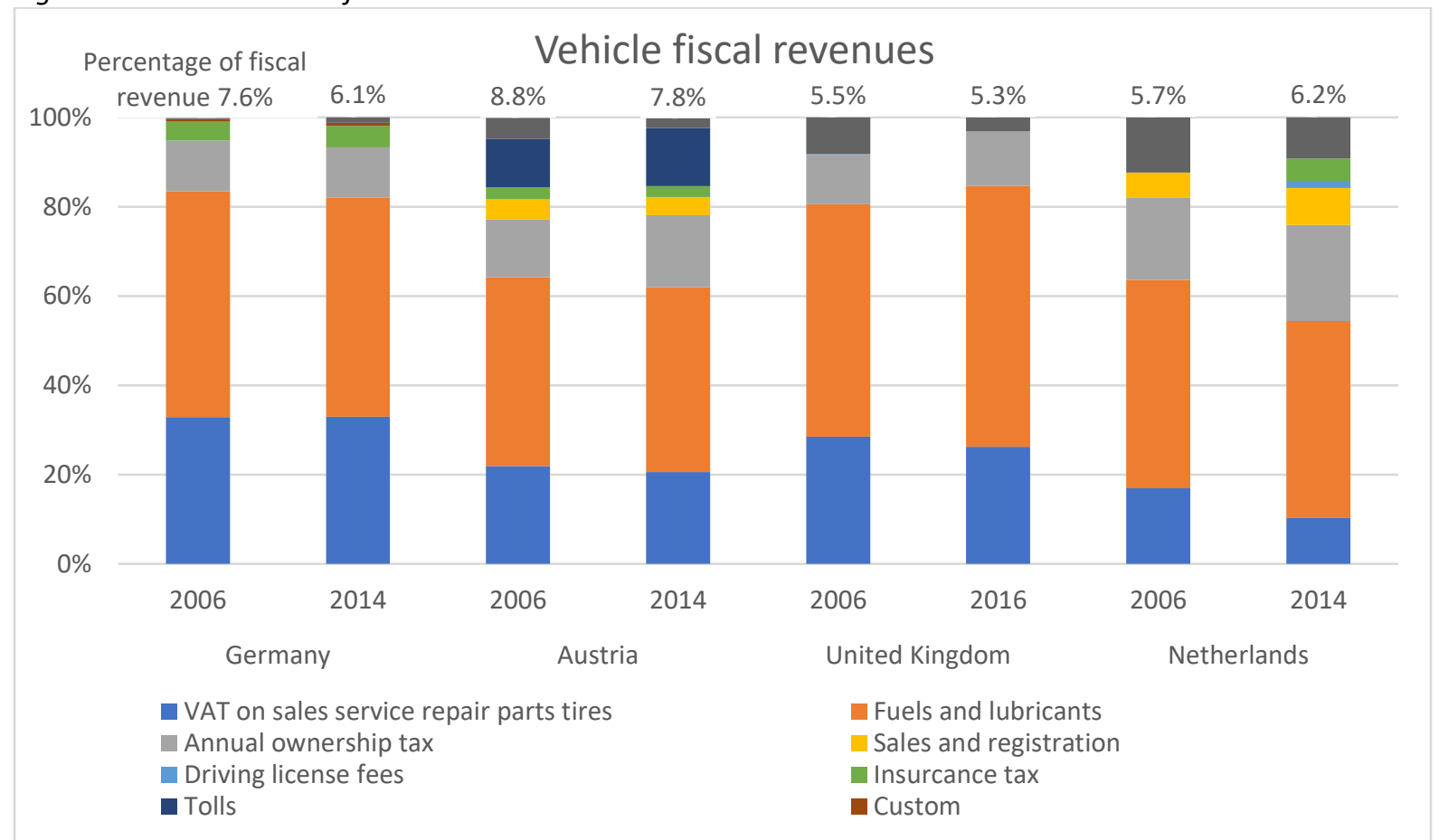

Data sources: ACEA $(2015,2017)$ and Eurostat (2018).

Vehicle-related fiscal revenues in Europe are levied predominantly at the national level. In Switzerland for example, $60 \%$ of revenues are collected at the national level, $35 \%$ at the state (i.e. Kanton) level, and $5 \%$ at the municipal level (mainly from parking). Vehicle related local sales taxes, also referred to as excise tax are a major revenue component for local governments, especially in the United States. For example, for the municipalities in the Commonwealth of Massachusetts, $73 \%$ of vehicle related revenues are in the form of excise taxes (between $25 \%$ and $97 \%$ ), with Boston at $41 \%$. For these municipalities, vehicle-related revenues amount to between $1.5 \%$ to $8 \%$ of municipal budgets, with Boston (4\%) being close to the average of 3.7\% (Mares et al., 2018). In the Netherlands, on average 10\% of municipal income is from parking fees and up to $27 \%$ in cities like Amsterdam (Statline, 2018; CBS, 2014). It is a general phenomenon that the positive net revenue at the federal level is used to counterbalance the substantial shortcoming at the municipal level (BFS, 2017). The share of municipal vehicle revenues in total vehicle revenues varies substantially in the OECD, from $2.8 \%$ in Denmark to $29.7 \%$ in New Zealand and with an average of $7.3 \%$ municipal revenue from transport taxes in the OECD.

Transport-related taxes and charges often serve multiple purposes, which can be assigned to two main categories: revenue generation and steering motives. In most countries, tax revenues generated by vehicle-related taxes enter the general budget; in some countries (such as the United States) taxes are partially earmarked for transport purposes. The revenue generation motive is also underlined by the relative share of vehicle-related fiscal revenues 
in overall fiscal revenues being rather constant over time for a given country (see Figure 1). In general, the role of tax instruments has changed over time, also for transport taxes. Historically the main objective of vehicle-related taxes was for general revenue generation but gradually the (environmental) steering effect has gained more prominence, especially in the EU (Kageson, 2005; Vanrykel et al., 2018).

Steering motives are present when taxes are designed such that they lead to a reduction of or compensation for negative externalities generated by transport, with the primary externalities being congestion, accidents, environmental pollution, and the use of public space. Fuel taxes increase in the per $/ \mathrm{km}$ consumption of a car and the distance driven, and hence affect the demand for vehicle kilometers driven as well as the car type (e.g., Brons et al., 2008). As registration and circulation taxes are often designed such that these encourage the purchase and use of more "environmentally friendly" cars, one can argue that these taxes also have a steering effect in terms of reducing (environmental) externalities.

Tax instruments have important welfare implications. Three main indicators are commonly used to assess the optimality of revenue generation: efficiency of the tax instrument, the governmental level at which the tax is collected, as well as redistribution and the counterbalancing of other market distortions.

The efficiency of the tax instrument is partially determined by the steering motive. Fuel taxes, for example, can be a suitable instrument to affect fuel efficiency and CO2 emissions (Innes, 1996; Anton-Sarabia and Hernandez-Trillo, 2014; Michielsen et al., 2015). Under certain assumptions, efficient prices correspond to the marginal social cost at the efficient level of traffic (Proost et al., 2002). When accounting for the marginal social cost of vehicles, the taxes on fuel are twice the optimal level in the United Kingdom but only half the optimal level in the US (Parry and Small, 2005). ${ }^{8}$ Urban and peak vehicle travel is currently underpriced which leads to deadweight losses from severe (i.e. hyper-) congestion (Duranton and Turner, 2011; Anderson, 2014, Adler and Van Ommeren, 2016; Adler et al., 2017). Nonetheless, vehicle tax policies can have unintentional consequences beyond the intended (direct) consequences. For example, a change in registration tax might simultaneously affect nominal circulation tax levels, demand for vehicle ownership, and vehicle kilometers traveled per vehicle (INFRAS, 2002).

Vehicle-related taxes may also have distributional impacts. Current fuel taxes count as regressive (i.e. being a relatively larger burden on low income groups), but some studies suggest that fuel taxes may actually be proportional (see for a discussion, Sterner, 2012). At the local level, transport-related taxes and charges are often in line with user/polluter-pays-principle (e.g. parking charges, traffic fines). Taxes that adhere to the user/polluterpays-principle result in more efficient market outcomes in the absence of other market distortions (Pigou, 1920; Small and Verhoef, 2007). Even if user fees at the local level of governance (i.e. tolls and parking fees) are potentially regressive and henceforth sometimes criticized for equity reasons, redistribution should generally be tackled at the national level (Ahmad and Brosio, 2015). Overall, taxes should recognize the notion of fairness, differentiation and harmonization as public finance is normative (Tresch, 2014).

\subsection{Expenditures}

Vehicle-related government expenditures of OECD countries range between $0.5 \%$ to $2 \%$ of GDP and $1.5 \%$ to $5 \%$ of overall government budget (i.e. fiscal expenditures). The list of expenditures towards land-based transport is broad

\footnotetext{
${ }^{8}$ With there are restrictions on the implementation of usage-dependent taxes, taxes on the purchase of vehicles are desirable (Fullerton and West, 2002, 2010; De Borger, 2001). Efficient pricing needs to consider capacity restrictions of the road network and the resulting congestion. See Bjertnæs (2017) for a recent example considering the efficient combination of taxes on fuel and vehicles.
} 
and there are substantial differences in the spending allocation between countries. It is challenging to find comparable data, as they accrue at different governmental levels, depending on regulations. Therefore, as an example case, we use the Netherlands for which good data exists and point out where statements can be generalized.

In 2017, the Netherlands spent 2.9\% (€8.9 billion) of public budget on land-based transport, see Figure 2. Construction and maintenance of highways and national roads constitute the lion's share and usually account for more than $50 \%$ of expenditures, exceeding the size of other public infrastructure spending, such as aviation, water, rail and energy. In the Netherlands, highway expenditures make up $56 \%$ of fiscal expenditures on land-based transport. Another $18 \%$ are spent on railways and on traffic rule enforcement. By comparison, in the US, 4.8\% (\$160 billion) of total fiscal revenues are spent on the highway system, with $28 \%$ contributed by the federal level and $72 \%$ by state and local governments (Musick and Petz, 2015).

Figure 2 - Fiscal expenditures

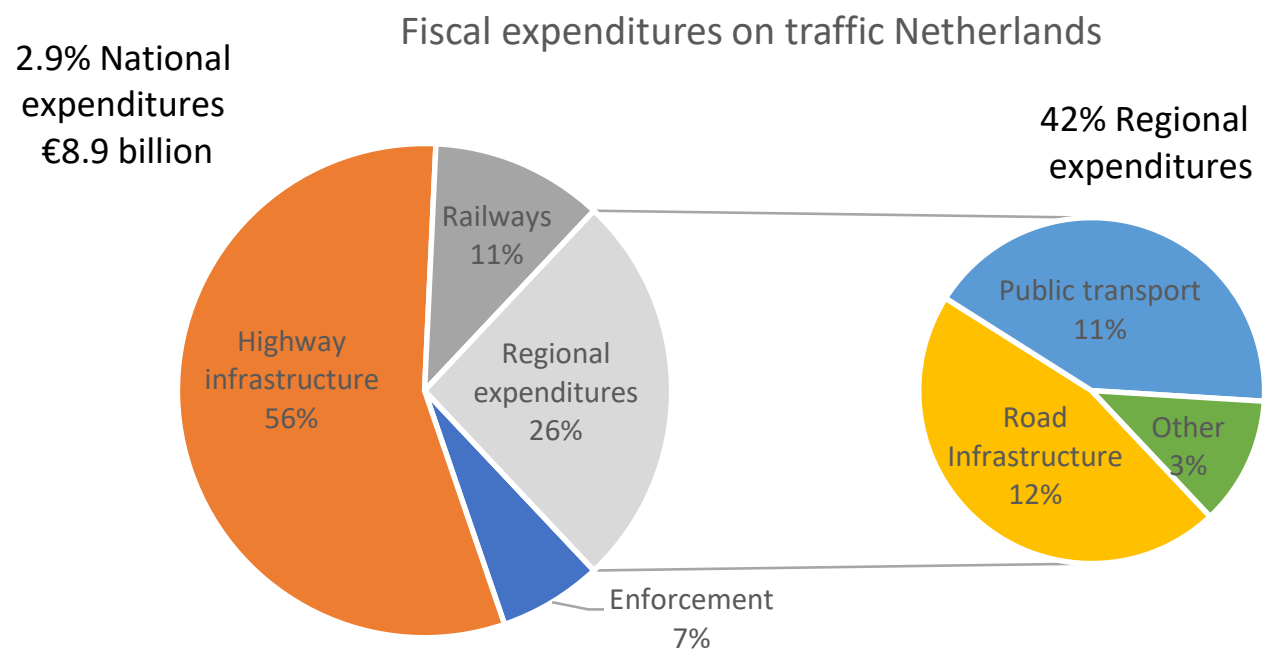

Sources: Wijnen and Stroeker (2009), Ministry of Infrastructure, Public Works and Water Management (2014), CBS (2017)

Regional governments contribute $12 \%$ of public finance towards road construction and maintenance in the Netherlands. This might seem relatively small, however, these $12 \%$ constitutes one-fifth (19\%) of the overall regional budget. Together with public transport, almost half (42\%) of regional finances are spent on transport (CBS, 2017). ${ }^{9}$ Subsidies to public transport are usually around $40 \%$ of operating costs in Western countries where the main economic reason for subsidizing public transport is a reduction of car externalities (Parry and Small, 2009; Anderson, 2014; Adler and Van Ommeren, 2016). We find a similar picture for Germany where $50 \%$ of transport expenditures are attributed to roads, $23 \%$ for rail, $10 \%$ on local public transport paid $60 \%$ on the national level, $27 \%$ by cities and $10 \%$ by regions (Link and Kunert, 2017).

Another cost to the government, which is typically not mentioned in statistics as the ones presented in Figure 2, as it only accrues indirectly, are subsidies to electric vehicle sales in the form of tax exemptions, tax credits and additional advantages such as waivers of parking fees, charges and tolls.

\footnotetext{
${ }^{9}$ Regional governments can use revenues from transport such as parking fees for extra spending on mobility. Local governments do not receive funding for mobility in the Netherlands. $4 \%$ of the national budget for mobility is from the EU.
} 


\subsection{Summary}

In summary, a substantial share of government expenditures and revenues is transport-related. On average, fuel taxes and transport-related VAT contributions make up $70 \%$ of vehicle-related taxes. Typically, fiscal revenues at the local level, such as from parking, are relatively low in absolute terms, but often constitute a substantial share of revenues for local governments (up to 30\%). Expenditures on road-based transport make up a substantial share in the fiscal budgets of national governments (typically, about 1-3\%) and regional governments (typically, about 3$30 \%)$.

There are similarities in the percentage of public revenues and expenditures associated with road transport between countries, but the governmental level at which revenues are collected, as well as the type and justification for the taxes differ substantially across countries. In countries such as the US, expenditures at the national and state levels are similar in size. In many European countries such as Germany and the Netherlands, spending at the national level is much greater that at the local level. Transport related fiscal expenditures amount to a large share of overall regional budgets. They also take up a large share of expenditures at the supra-national level: almost $9.4 \%$ of the EU budget is spent on transport through earmarked cohesion funds. ${ }^{10}$

When comparing the level of revenues with expenditures, Gomez and Vassallo (2013) find that EU countries generate enough revenues from transport to subsidize other non-transport-related expenditures, whereas in the US the public sector subsidizes transport-related expenditures. The US road transport system has been in a funding crisis for the past two decades, and has a continuous shortfall of about \$126 billion per year (Oh and Sinha, 2010; Congressional Budget Office, 2012). One reason is that federal fuel taxes have not been inflation adjusted since 1993 and that capital spending is lower than the required \$126 billion/year to maintain the federal highway system's performance (Morris, 2006; Congressional Budget Office, 2012). The US earmarks approximately $50 \%$ of fiscal revenues from vehicles for road expenditures but for the EU it is only around $10 \%$ (Gomez and Vassallo, 2013). ${ }^{11}$

\section{ACES}

\subsection{Adoption and outlook}

This section describes the characteristics of ACES and discusses the expected timeframe of their introduction. The time frame is a subject debated by the industry (e.g. Waymo, Tesla) as well as by public and private research institutes (Silberg et al.,2012; Saffo and Bergbaum 2013; KiM, 2015; Kass et al., 2016; Ranft et al. 2016; Bloomberg, 2017). ${ }^{12}$ ACES technologies (i.e. automation, connectivity, electrification, and shared ownership) are highly interdependent, but have emerged at different times and are often discussed independently. In this section, we discuss these technologies in turn and motivate why these are separately, but even more so jointly relevant to public finance.

\footnotetext{
${ }^{10}$ For the 2007 to 2014 period, the EU earmarked 10 billion per year in cohesion funds directed at road infrastructure and $€ 20.35$ billion in Transport European Network program (TEN-T) (Transport \& Environment, 2011).

${ }^{11}$ Even so earmarking is uncommon in the EU, expenditures decisions often take revenues into account (INFRAS, 2002).

12 Earlier studies assumed later introduction dates than more recent studies as technological and regulation barriers were overcome faster than expected. Newer, Anglo-Saxon studies also point to a much more rapid adaptation and earlier market saturation with most studies expecting western countries' car fleets to be almost entirely autonomous by the year 2050 .
} 
Autonomous vehicles are a broad category for vehicles that have the capacity to drive without human input (and hence are often referred to as driverless or self-driving vehicles). There is a continuous spectrum of vehicle autonomy. For this paper's purpose, we regard vehicles as autonomous when these can operate longer distances without the assistance of a driver (broadly in-line with Level 3 classification and above, see SAE International, 2016). Autonomous vehicles at level 3 are currently road tested and are expected to become commercially available before 2020. Autonomous ride-sharing depends on full-automation (level 4 and above) which is forecasted to be available on the market starting in the 2020's (Navigant Research, 2016). There is a wide consensus that autonomous vehicle diffusion is imminent, and that diffusion will take the form of a Sigmoid curve, where initial adaptation is slow but followed by years of rapid adaptation, and that by 2040 the majority of vehicles in the Western world will have the capability to drive autonomously (Rogers, 1995; Leech et al., 2015; Kaas. et al., 2016; Ranft et al., 2016).

The diffusion of electric and hybrid vehicles has been rather slow so far. For example, in the EU, despite a wide range of incentives and a growth in sales, electric vehicles made up only $0.7 \%$ of the new car sales in 2014 (Tietge et al., 2016). Ambitions of policy makers and the industry are high, not least due to the goals set in the Paris Climate Agreement. For instance, from 2019 onwards, Volvo aspires to produce only hybrid and fully electric cars as a commitment to an electric car future. ${ }^{13}$ The German Federal Council (Bundesrat) declared the intention to permit only emission-free vehicles from 2030 onwards EU-wide. ${ }^{14}$ Britain, France and China have set similar targets for the electrification of vehicles in line with the Paris Climate Agreement. Results concerning stimulating effects on electric and hybrid vehicle sales are mixed, with sales in Europe averaging 1.5\%, the US 5\% and Japan $20 \%$ of new vehicles (Zhou et al., 2015). For instance, the Dutch government exempted plug-in hybrids from registration and circulation tax for a 3-year period, provided scrapping bonuses for high pollution vehicles, and waved charging and parking fees. This stimulus was accompanied by a 5\% increase in electric vehicle sales in 2013 at a cost of $€ 500$ million, which is $0.18 \%$ of fiscal expenditures and $5 \%$ of transport expenditures (RVO, 2013; Volkskrant, 2014). The diffusion of electric vehicles depends heavily on regulation and the price of batteries. Prices for car batteries are expected to drop by a factor 10 within the next 10 years (The Economist, 2017). This reduction in cost is speculated to result in cost parity between electric vehicles in comparison to conventional gasoline by the end of 2018 (Walker and Johnson, 2016). By mid-century, 90\% of vehicle sales are expected to be electric (Morgan Stanley, 2017). Autonomous cars are likely to be electric. A main reason is that electric cars are (so far) more expensive in their production, but the operating costs per $\mathrm{km}$ are comparably lower. Electric cars will thus be especially favorable for users or groups of users with high mileage, such as it is likely to be the case with autonomous cars in fleet ownership. Conversely, electric cars may benefit from automation, especially if they are capable of accessing charging stations and completing the charging without need for human assistance.

The concept of shared-ownership of vehicles comprises a number of related services such as ride-hailing (e.g. Lyft, Mytaxi), ride-sharing (incl. carpooling, e.g. BlaBla car), shared ownership (Car2go, Greenwheels) and Mobility-as-aService (MaaS). ${ }^{15}$ These sharing concepts are highly compatible with autonomous electric driving and are likely to become more common once autonomous cars are on the market. In line with an increase in shared transportation, private ownership of cars is likely to decline for the following two reasons. First, autonomous cars will be more expensive than traditional cars (due to the additionally required equipment such as high-quality sensors), and hence ownership only pays off with high mileage. Conversely, shared ownership of autonomous vehicles is expected to yield cost savings to users who travel less than $10,000 \mathrm{~km} /$ year which is almost half of all car travelers in Europe

\footnotetext{
13 https://www.media.volvocars.com/global/en-gb/media/pressreleases/210058/volvo-cars-to-go-all-electric

${ }^{14} \mathrm{https}$ ://www.bundesrat.de/DE/plenum/plenum-kompakt/16/948/070.html?view=main\%5BDrucken\%5D

${ }^{15}$ We define MaaS as an integration of transport services that provides multi-modal mobility without the necessity for private ownership of the transport mode(s).
} 
(Odyssee-Mure, 2015; Litman, 2017). Second, a critical mass of users for shared vehicles will probably be easy to reach, due to the expected convenience and affordability (the operating costs of shared services are expected to be low, especially if no driver is needed any longer). The resulting Mohring effect (Mohring, 1972) will lead to reductions in waiting time. All these reasons point towards ACES being to a large extent in shared (fleet) ownership. Not only car-sharing, but also ride-sharing is likely to become more common with the introduction of ACES: coordination among vehicles will become much easier (even route adjustments during the drive can be made easily by an underlying algorithm), and the fact that travel time can be used more productively renders detours for pick-ups and drop-offs less costly. Hence, once transport in shared autonomous vehicles is more affordable than in private vehicles, price-sensitive users, in particular in cities can be expected to switch to the former.

In a stated preference study concerning the willingness to pay for shared and connected autonomous vehicles in Austin (Texas), 41\% respondents were willing to use shared autonomous cars at least once a week and an additional $15 \%$ as their regular transport option under the assumption of cost parity with regular vehicles (Bansal et al., 2016). Another study by Cornet et al. (2012) found that a third of urban Germans are predicted to be car-sharing users by 2022 and that attitudes are gradually changing with $87 \%$ of respondents aware of the sharing concept and $31.5 \%$ of respondents stating that they have gathered further information on car-sharing. Car-sharing has seen double digit annual growth in profitability since 2005 (Cornet et al., 2012). Currently, 50\% of global car-sharing users are in the $\mathrm{EU}$, with an annual compound growth rate of around $20 \%$ in users projected to reach 16 million users in 2020 (Schiller et al., 2017). Potentially, by 2030, every tenth vehicle sold is shared through some sort of car-sharing scheme (Kaas et al., 2016).

By 2030, ride-sharing is expected to increase substantially, possibly replacing two-thirds of the current taxi market (Burgstaller et al., 2017). Their forecast predicts that $4 \%$ of inner city trips will be conducted via ride-hailing services in 2030 relying on one in fourteen cars produced ( $7 \%$ of total car production vs. $3 \%$ currently). ${ }^{16}$ However, it can be assumed that shared, autonomous transport will be accessible to $70 \%$ of population living in urban centers by 2035 (Walker and Johnson, 2016). Chen et al. (2016) expect that each shared autonomous electric vehicle can replace 3.7-6.8 privately owned vehicles but that cost competitiveness crucially hinges on recharging automation. Another study projects that MaaS will account for $40 \%$ in 2035 and reach around $80 \%$ in the decade between 2040 and 2050 (Schmidt et al., 2018). Car- and ride-sharing are predicted to be predominantly attractive in urban settings due to price advantages from economies of scale. Waiting times for ACES are expected to be substantially longer in less densely populated areas (e.g., Bischoff and Maciejeweski, 2016).

Connectivity and digitalization are a pre-requisite for efficient car- and ride-sharing. For the actual operation of ACES, the case is less clear. For instance, Alphabet, the parent company of Google and Waymo, intends to keep ACES not continuously connected to the internet to prevent security threats whereas companies such as Audi and BMW plan cars that communicate with each other and with the infrastructure (Condliffe, 2017). Connectivity certainly plays a large role in reducing traffic externalities and in making congestion more predictable (Hensher, 2018).

To illustrate the above discussed trends, we combine 16 studies including 25 forecasts for vehicle automation, electrification and sharing in the developed world to a consensus forecast, shown in Figure 3. For simplicity and tractability, we assume an equal probability for all forecasts that predict vehicle automation at and above level SAE 3 automation. Although individual forecasts vary greatly, the consensus forecast exhibits similar growth rates of the three technologies. Automation, connectivity and electrification take off somewhat earlier, grow faster and reach

\footnotetext{
16 Private car penetration in cities would decline from $31 \%$ in 2015 to $27 \%$ in 2030 . Ride-hailing cars account for $2 \%$ of the overall fleet by 2030, vs. $0.3 \%$ today (Burgstaller et al., 2017).
} 
an almost complete saturation level by 2040 , whereas vehicle sharing is predicted to reach $60 \%$ of new vehicle sales by 2035 . Unsurprisingly, more recent forecasts have an information advantage over older publications, and the consensus forecast only approximately follows an (s-shaped) sigmoid transition path usually associated with diffusion of innovations, which is not at least due to the aggregation of the underlying forecasts. Also, not all forecasts include predictions until 2050, so after 2040 fewer forecasts are used and almost none of the studies concerning sharing include predictions past 2030.

Figure 3-Consensus forecast ACES diffusion

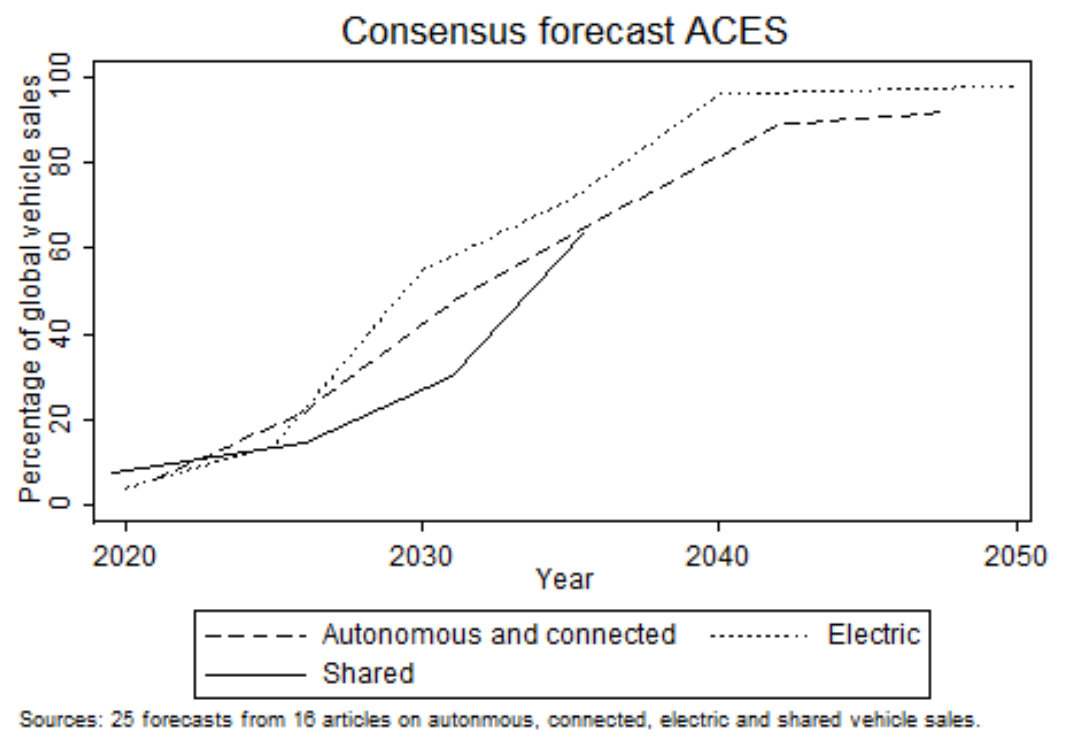

Sources: Underwood (2014); Ihs markit (2014); Leech et al. (2015); KiM (2015) Frost and Sullivan (2016); Kaas et al. (2016); McKerracher et al. (2016); Ranft et al. (2016); Walker and Johnson (2016); Schiller et al. (2017); Schmidt et al. (2018); Litman (2017); Bloomberg (2017); ING (2017); Morgan Stanley Research (2017); Graham (2018)

As ACES are more expensive than cars with combustion engines, it is expected that ACES will quickly penetrate the transport service sector (both goods and passengers) as well as the luxury private car sector. The expected higher price of ACES compared to conventional cars suggests that metropolitan areas might see a faster diffusion of ACES than rural areas, due to the higher potential for shared ownership in urban areas (McKerracher et al., 2016). On the other hand, rural areas might be the first to benefit from ACES technology due to the higher technology requirements that come with urban mixed traffic compared to rural roads and highways, which might slow down ACES diffusion in urban areas (Pernestål Brenden and Kristoffersson, 2018). Regarding electric cars, subsidies and tax exemptions have led to increases in electric vehicle sales in recent years (for instance in the Netherlands, Austria, and Norway), in particular for luxury car models used for business purposes. In the freight sector, electric vehicles are especially sought after for inner city deliveries where regulations on pollution are likely to become stricter.

Technology companies, car manufacturers and the finance industry are confident about the transition to autonomous vehicles. Current R\&D funding exceeds 36 billion US Dollars (Burgstaller et al., 2017), and 80 billion Dollars US for deals regarding investments, partnerships, and acquisitions in autonomous driving technologies (Kerry and Karsten, 2017). The time period between 2014 and 2017 has seen an almost exponential growth in new 
transportation start-ups as well as mergers and acquisitions in the autonomous vehicle segment (CBinsight, 2017).

\subsection{Fiscal aspects of ACES}

We discuss the expected fiscal effects of ACES by summarizing the findings of existing studies on the direct and indirect effects of ACES under the assumption that current (transport and fiscal) policies remain in place. While the effects cannot be predicted precisely due to the inherent uncertainties associated with technological innovation, their direction can be anticipated. ACES have numerous fiscal implications, which are highly interdependent comparable to transmission through 'ripple effects' (Milakis et al., 2017b).

\section{Decrease in fuel tax revenues and increase in electricity tax revenues}

ACES are expected to lead to a substantial decrease in tax revenues from combustion fuels (as well as VAT and/or sales taxes levied on top of the fuel price and the associated fuel tax), due to electrification of vehicles and efficiency increases. By 2030, new car sales are expected to be close to $100 \%$ electric in Europe and the US, and up to $50 \%$ globally (McKerracher et al., 2016). Under these assumptions, demand for vehicle fuels is expected to decline by as much as 75 percent between 2015 and 2030 (McKerracher et al., 2016).

In parallel, electricity demand will go up. By 2030, electric vehicles are expected to account for $3 \%$ of global electricity demand (McKerracher et al., 2016). Annual electricity consumption from EVs is projected to increase from 6TWh in 2016 to 1,800TWh by 2040, adding 8\% to global electricity demand by 2040 (Bloomberg, 2017).

However, foregone fiscal revenues due to declining fuel tax revenues are unlikely to be counterbalanced by higher tax revenues from electricity taxes: oil products for travel (i.e. combustibles) are currently taxed more than 10 times higher than oil products for electricity production in the OECD (2013) per ton CO2 emission. Coal, a major input to electricity generation in countries such as the US and Germany has an even lower tax rate per ton CO2 emission than oil used for heating. As a result of electrification, tax revenues from combustibles are thus expected to decline noticeably (Wakeley et al. 2008; NSTIFC 2009; Cambridge Systematics et al. 2012).

At the vehicle level, efficiency gains can possibly also be achieved due to automation (independently from the engine), due to more efficient routing, platooning and start-stop avoidance. An overview study by Brown et al. (2013) suggest efficiency gains from these three factors in the range of 5\%,10\% and 15\%, respectively. Silberg et al. (2012) find that platooning could reduce highway fuel use by up to $20 \%$ solely due to the decreased drag coefficient from drafting (Fagnant and Kockelmann, 2015). However, Gawron et al. (2018) argue that the net efficiency gain may actually be much smaller (around $9 \%$ in their base case), as the system components enabling autonomous driving (computing power, additional weight, etc.) may lead to an increase in power consumption of 3-20\% compared to non-automated vehicles.

At the systems level, changes in energy consumption from vehicle usage, and their effect on revenues from taxes imposed on electricity, are difficult to predict, and closely related to the future demand for ACES-based mobility, the extent of sharing, as well as operational characteristics that determine the extent of idle rides for relocation (location adjustment for demand reasons), recharging and parking purposes.

\section{Decrease in registration and circulation tax revenues}


Currently, even during peak hours, only $12 \%$ of US cars are in use (Silberg et al., 2012). In large metropolitan areas, $95 \%$ of trips tend to be shareable (Tachet et al., 2017). Three-thousand shared ACES (a third of the current taxi fleet) could supply $97 \%$ of all current 3 million New York city yellow cab rides, and this could be reduced to $15 \%$ of the current fleet if ACES came in the form of mini-vans with 10 seats (Atherton, 2017). For Lisbon, if $10 \%$ of the vehicle fleet were ACES, these could supply all transport when public transportation is left in place (Martinez and Christ, 2015). Similar figures apply to $r$ Austin (Liu et al., 2017).

Car-sharing and ride-sharing may lead to a decrease in the number of registered vehicles in the Western world, as a smaller vehicle fleet can provide similar or even higher levels of mobility (Fagnant and Kockelman 2013; Martinez and Christ, 2015; Schonberger and Gutmann, 2013). Global vehicle sales might, however, still increase due to an increase in motorization rate. In the Western World, a decrease in registered vehicles is likely to translate into a decline in registration and circulation tax revenues given that current taxation rules remain in place. The decline in registration tax revenues might be dampened if car utilization and in turn the car turnover rate increase (Burgstaller et al., 2017).

\section{Public sector - roads, energy, telecommunication and transit}

Investments in infrastructure (e.g. telecommunication and energy) and subsidies to public transport may increase with the introduction of ACES, in particular in the short and medium run.

The electrification of the vehicle fleet requires investments into smart electricity grids. EVs are expected to increase global electricity consumption moderately (until 2040 by $8 \%$ according to Bloomberg, 2017). However, they will contribute to peak-load profiles, in turn requiring additional storage solutions and efficient grid management at the operator level, as well as policies that encourage off-peak charging to prevent power supply and financial shortfalls (Bloomberg, 2017). Research by Morgan Stanley (2017) predicts that global investments of $\$ 2.7$ trillion are required to prepare the power grid for 500 million electric vehicles until 2040. Under this calculation, the US and the EU, accounting each for one quarter of the global vehicle fleet would need to invest around \$250 billion (1.5\% of GDP) annually until 2050. By comparison, revenue gains from electricity provision and taxation of electricity are negligible (see the previous subsection on fuel revenues and a study conducted by OECD,2013).

ACES might affect the costs of road infrastructure maintenance and construction. A higher number of VKT (due to induced demand) is generally associated with higher costs for road maintenance (Clark et al., 2018). In terms of construction, ACES may require less costly safety features such a road shoulders and traffic signs, as well as lower investments in noise protection measures due to electric engines being quieter than fuel combustion engines (Silberg et al., 2012; Fagnant and Kockelman, 2014). Moreover, ACES are expected to use road capacity more efficiently by lowering the necessary safety distance between vehicles, and thereby improving road capacity, and reducing the need for new road construction. However, making ACES use road space more efficiently may require vehicle communication through connectivity and a high market penetration ( $>40 \%$ ) of autonomous vehicles (Van Arem et al., 2006). The cost for infrastructure that is necessary for vehicle connectivity, in particular telecommunication technologies, may be high and in constant need of upgrading with advances in technology (Silberg et al., 2012). Therefore, the effect of ACES on public expenditures on road construction and maintenance is 
fairly unclear for lower penetration rates (Eugensson et al., 2013; Wagner et al., 2014). At considerable ACES market penetration, Silberg et al. (2012) expect a small, but significant decline in infrastructure spending by $10 \% .{ }^{17}$

Public transport scenarios for ACES are highly speculative, since ACES and public transport are not exclusive concepts. In the future, ACES could serve an important role in public transport. For example, the problem of how to travel the "last mile" of a journey after a shared long-distance travel could be solved through innovative MaaS concepts (Begg, 2014). ${ }^{18}$ Low density and low quality public transport is expected to be replaced by ACES in the long term (Litman, 2017), since losses from a shrinking user base cannot be recovered through higher fares that would accelerate the downward service spiral and increases in already large subsidies. Current subsidies to local transit in Europe are between $40-60 \%$ of operating cost with even higher relative subsidies in most cities in the US. Also, longdistance rail transit requires large up-front infrastructure investments with large investment horizons (+30 years) that is going to come under pressure from ACES (Silberg et al., 2012). ${ }^{19}$

\section{Macro-economic effects}

ACES can (indirectly) affect income tax, corporate tax, capital gains tax and welfare expenditures via the labor market, via the taxation of car manufacturers and fleet operators, and via ACES' impacts on the wider economy (including the freight sector). At this point, however, there remains a high level of uncertainty concerning the macroeconomic effects of ACES, not least because the outcomes depend on public policies. ${ }^{20}$

It is generally expected that there will be an overall positive effect of ACES on productivity and GDP. The forecasted effects are highly speculative and tend to be in a range of an adding 4-12\% to GDP in the long run. This is in line with a $0.15 \%$ increase in GDP growth rate from autonomous vehicles between 2021 and 2050 for the EU and the US (Shanker et al., 2013; Ranft et al., 2016;). Productivity gains depend on mobility gains but also on cost savings (detailed throughout Section 3, see also Shanker et al., 2013). Socio-economic benefits of autonomous vehicles are expected to be around $f 50$ billion (2\% of GDP in 2018) per year by 2030 for the United Kingdom (Leech et al., 2015). A recent study by Karpilow and Winston (2016) expects for California an annual boost to the GDP growth rate by $1.8 \%$ and an increase in annual labor earnings by more than $\$ 100$ billion, under the condition that ACES can reduce congestion to a minimum. Note that most studies focusing on macro-economic effects of automated driving combine freight and passenger transport, also because the macro-economic effects are hard to disentangle between freight and passenger transport.

ACES may strongly affect the labor market, most evidently by reducing the number of jobs in the transport and logistics sector (Shanker et al., 2013; Davidson and Spinoulas, 2015; Guerra, 2016; Alonso Raposo et al., 2018). To underline the size of this issue, the EU transport sector employs $5 \%$ of the workforce and an additional $2 \%$ for

\footnotetext{
17 Platooning on highways can increase capacity by up to $500 \%$ but according to a study by the Boston Consulting group, Amsterdam and similar cities requires substantial road capacity upgrades to allow for autonomous vehicles. http://nltimes.nl/2016/10/11/amsterdam-ready-handle-self-driving-cars-bcg.

18 Mobility options do not necessarily have to decrease in the absence of public transit. For instance, Innisfil, a 36,000-inhabitant town near Toronto, is relying on Uber to provide last-mile public transit services (May, 2017).

${ }^{19}$ High speed mass transport services, e.g. high-speed rail, might have sufficient comparative advantage to autonomous vehicles rendering complementary to ACES. Local public transit services, however, are likely to be close substitutes to ACES and thus to suffer substantially under ACES competition. This will increase pressure on local public finance that subsidizes these services or alternatively these services are no longer provided.

${ }^{20}$ Bertoncello and Wee (2015) speculate that ACES bring about changes in spending patterns because of more leisure time from reductions in travel costs and therefore a higher disposable income.
} 
employment in related sectors of the economy (ACEA, 2018), and truck drivers (and related jobs) are the most common profession in the majority of US states (NPR, 2015). By 2030, ride-sharing is supposed to increase eight-fold and replace two-thirds of current taxi market, rendering potentially 2.6 million drivers globally redundant, according to a study conducted by Goldman Sachs (2017). Additional jobs that might be replaced include vehicle maintenance staff, employees at driving schools, employees of insurance companies, park and traffic surveillance staff, and even emergency room staff (Hörl et al, 2016). ${ }^{21}$ The reduction in employment is expected to predominantly affect lowincome jobs. New jobs are expected to be created in the more advanced tech sectors, requiring a different skill set (Alonoso Raposo et al., 2018) and potentially leading to a labor market polarization (see Thuemmel, 2018).

At least for a certain period, the automation of labor in the transport sector is predicted to progress faster than new jobs in this sector will be created, in particular in the absence of concrete policy measures. The ITF (2017) proposes the introduction of a licensing system on ACES in freight in order to slow down the introduction of ACES, thereby supporting a labor market transition that avoids major unemployment spills. The labor market outcomes of ACES will also depend on public policy regarding skill upgrading through education (Ranft et al., 2016). The topic relates to the larger discussion on how automatization will affect the labor market and society as a whole (Frey and Osborne, 2017), and which measures should be taken (e.g., basic income, higher taxes on capital). ${ }^{22}$

The negative employment effects may be partially counterbalanced by better matching in the labor market due to a higher acceptance for longer commuting distances and for higher mobility in general ${ }^{23}$. An increase in mobility and therefore an improvement in accessibility has benefited the United States and Europe substantially in the last decades (Duranton et al. 2014; Adler et al., 2018).

\subsection{Externalities}

In this sub-section, we discuss the possible effects of ACES on transport-related externalities. These are relevant in the context of ACES and public finance, as taxes should be designed such that externalities are internalized by users.

\section{Congestion}

One percent of GDP is lost in travel time due to congestion each year in the EU-28 (European Commission, 2011; CEBR, 2014). Especially urban centers are affected by congestion. The TomTom traffic index shows that congestion levels in urban areas are deteriorating, with larger urban areas experiencing average travel times $66 \%$ above free flow levels and up to twice as long for peak hours. ${ }^{24}$ In monetary terms, for example, residents of Los Angeles lose on average $€ 5,700$ to traffic jams each year (The Economist, 2014).

ACES are predicted to have a large effect on the vehicle kilometers traveled (VKT), especially in the medium and long run (Litman, 2015). The reason is induced demand due to more efficient, comfortable, inexpensive and possibly also

\footnotetext{
${ }^{21}$ Although the car industry is already highly automated, there are concerns that even more jobs will be lost because EVs are much simpler to assemble than cars with combustion engines (The Economist, 2017).

${ }^{22}$ Concrete measures targeted more specifically at the introduction of ACES can be found in the "Driving Future Platform" of the EU Parliament: https://connectedautomateddriving.eu/event/4th-driving-future-event

${ }^{23}$ Karpilow and Winston (2016) estimate that a reduction in congestion may lead to an increase in employment by up to $15 \%$ in California.

${ }^{24}$ https://www.tomtom.com/en_gb/trafficindex/list?citySize=LARGE\&continent=ALL\&country=ALL
} 
reliable ${ }^{25}$ provision of mobility services, and current steering instruments becoming widely obsolete: taxes on fuel will lose their effect on electric vehicles, with electricity being significantly less taxed than gasoline, and parking charges will not prevent autonomous vehicles from entering areas with land scarcity as they can keep cruising or park elsewhere (Ostermeijer et al., 2018). Cheaper car-based mobility will lead to people switching from transport modes with more efficient space usage (public transport, cycling or walking) to ACES. ACES will also attract new user groups such as the elderly, disabled, and young people, who currently tend to be restricted in engaging in independent mobility. Diffusion of ACES will also lead to additional and longer trips because of increased travel comfort, low costs and the fact that travel time can be used productively. Moreover, idle rides may take place in order for ACES to be able to make use of unpriced parking, for re-charging purposes, or to optimize vehicle availability according to expected demand patterns (empty ACES have no value of time, i.e. they do not experience disutility from spending time in congested conditions as human drivers do, see for instance Kaddoura and Bischoff, 2017).

The predicted increase in congestion may be partially dampened by ride-sharing. However, it is fairly unclear at this point to which extent ride-sharing will be adopted by consumers, especially in less densely populated areas and whether it indeed will serve the promise of reducing congestion and traffic (Hensher, 2018). In a review of 20 simulation studies, Pernestål Brenden and Kristoffersson (2018) find that there are large variations in the anticipated changes in vehicle kilometers traveled because these depend heavily on the assumed value of time and the extent of ride-sharing which in turn depends on incentives and regulations. Similarly, they find support for the expectation that with the introduction of ACES, VKT increase most during peak hours in urban areas compared non-urban areas and off-peak hours. Although estimates for the increase in VKT are highly speculative at this point, we summarize some numbers so far stated in the relevant literature: Trommer, et al. (2016) estimate that autonomous vehicles are likely to increase total vehicle travel by $3-9 \%$ by 2035 , and passenger miles might even increase by $25 \%$ (Fagnant and Kockelman, 2014; Martinez and Christ, 2015; McKerracher et al., 2016). For the United States, vehicle kilometers traveled are predicted to grow by $14 \%$ from non-drivers alone, which might add $40 \%$ of VKT (Brown et al., 2013; Harper et al., 2016).

An increase in VKT can increase road congestion significantly. Road congestion itself is a function of vehicles on the road given the available infrastructure. Higher levels of congestion during peak hours result in hyper-congestion where speed and vehicle flow are declining, and inefficient production of travel is especially costly, with welfare losses up to 50 times those of congestion (Adler et. al, 2017). ${ }^{26}$ Since the speed-flow relationship is non-linear and backward-bending, even small increases in VKT can result in large travel time increases and hyper-congestion, in particular, as the current infrastructure does not allow for an increase in VKT during peak hour travel where congestion is already high.

As discussed in Section 3.2, ACES may also affect road capacity and traffic flow. The effect of autonomous vehicles is expected to be negative at low levels of automation and market penetration. For example, a traffic simulation by Calvert et al., (2017) found that low-level automated vehicles in mixed traffic have a negative effect on traffic flow and road capacity, and that improvements in traffic flow occur at penetration rates above $70 \%$. However, above $50 \%$ autonomous vehicles penetration, simulation studies find gains of around 5-15\% in capacity at bottlenecks and 15\%-

\footnotetext{
${ }^{25}$ Hensher (2018) argues that with a high penetration rate of AVs congestion will become more predictable.

${ }^{26}$ Note that these numbers may change if the value of travel time decreases due to a higher travel comfort and more productive use of travel time.
} 
$20 \%$ without bottlenecks (see Milakis et al. 2015, 2017a for an overview). ${ }^{27}$ In the congestion context, we also need to distinguish between ride-sharing that might reduce the number of cars on the road and thereby congestion, whereas car-sharing has no positive effect on road use per se. The former case can be reconcilable with an increase in vehicle kilometers traveled. In contrast, increasing road capacity through road construction tends to be followed by an upwards adjustment of travel demand, postulated as the law of road congestion by Duranton and Turner (2011).

Finally, more VKT would increase toll revenues for countries with a toll system. As we show in Section 2.2, currently, road tolls are only a fraction of current revenue streams and so the absolute increase is likely going to be small when current toll policies are kept in place.

\section{Environment and public health}

Currently, road-based transportation consumes about one fifth of total energy and contributes a similar share to CO2 emissions with strong implications for the global climate (OECD, 2013). Furthermore, traffic is a main driver of local emissions, leading to an increased incidence of cardiovascular and mental illnesses (Maizlish et al., 2013).

$\mathrm{CO} 2$ and local emissions accrue both in the usage of cars as well as during the car production and potential recycling. At the vehicle level, both in the production as well as the recycling, electric vehicles tend to be more energy-intensive than cars with a combustion engine (Faria et al., 2012). To which extent this translates into increased $\mathrm{CO} 2$ emissions (again at the vehicle level) depends on the source of the energy used in the production and recycling processes. At the system level, the emissions associated with production and recycling are driven by the number of cars (which as indicated above - is likely to decrease in Western countries, but likely to further increase in developing countries). Local environmental pollution in the production process (and, closely related, health effects among the workers and local population around extraction sites) may occur in the extraction of minerals required for battery production (e.g. cobalt, lithium). However, also the extraction of oil and gas is associated with similar problems.

Regarding the usage of ACES, the main environmental and health benefits to the consumer comes from electrification, which leads to a reduction of the external air and noise pollution costs, and reductions in greenhouse gases. Again, the latter is strongly dependent on the source of electricity used for charging the vehicles. The reduction in local pollution due to electrification can be substantial. But one should be aware that between $10 \%$ to $50 \%$ of external air pollution from vehicle use is due to other sources than fuel combustion such as tires and brake particles (Grigoratos and Martini, 2014).

The effects of automation of the car fleet (without electrification) on greenhouse gas emissions are unclear, with some analyses projecting a reduced environmental impact (Brown et al., 2014; Greenblatt and Shaheen, 2015), while others project that an increase in vehicle kilometers traveled could nearly double such emissions (Wadud et al., 2016).

Improved motorized mobility from ACES might reduce non-motorized, active mobility such as cycling and walking. Physical inactivity costs the United States more than $\$ 77$ billion in direct medical expenses alone (Pratt et al., 2000). For instance, the transition from bicycle use to car-based transport for short trips would can result in a reduction of

\footnotetext{
27There are studies that predict much larger capacity gains such as Pinjari et al. (2013) who estimate that connected AVs will cause a 22 percent increase in highway capacity at 50 percent market penetration, 50 percent capacity increase at 80 percent market penetration, and 80 percent increase at 100 percent market capacity.
} 
3-14 months in life-years, not even accounting for pollution and accidents risks (De Hartog et al., 2010). Hence, if ACES are widely available at low costs, negative health effects from lower levels of physical activity may arise.

\section{Road Safety}

Traffic accidents lead to approximately 1.25 million fatalities annually and reduce the gross domestic product by up to $2.5 \%$ (Elvik, 2000; WHO, 2017). Traffic accidents also account for substantial health care expenditures: e.g., 1.5$2 \%$ of overall health care expenditures in the United States (Shanker et al., 2013). Approximately $93 \%$ of car accidents are due to human error (Fagnant and Kockelman 2015). By reducing these errors, ACES may substantially lower the frequency and severity of car accidents (Jonas et al. 2014). However, this applies mainly in regimes with high ACES penetration rates (Litman, 2014). In regimes with low ACES penetration rates, due to offsetting behavior in terms of risk adjustment and rebound in increased travel, the number of accidents might actually go up (Ecenbarger 2009; Lin 2013; Ohnsman 2014; Fung 2015; Sivak and Schoettle, 2015; Litman, 2017). Users of ACES may also benefit by paying lower insurance fees; for instance, the partially autonomous Tesla is estimated to have a $40 \%$ lower accident risk than comparable less autonomous vehicles by the National Highway Traffic Safety Association (Muoio, 2017; NHTSA, 2018).

\section{Parking and the use of public space}

Private cars are currently in use only about $5 \%$ of the time. In a city like London, $16 \%$ of space is used for parking facilities (Skinner, 2016). Cars that are shared have a higher utilization rate and are therefore parked less often. When cars are connected, parking search costs (which constitute a substantial share of overall congestion costs), can be reduced substantially (Arnott and Rowse, 1999; Van Ommeren et al., 2012; Kaas, H. W. et al., 2016). Further, it is anticipated that higher levels of car automation can reduce the need for parking spaces in dense urban areas by allowing vehicles to park in places where land is cheaper. This, however, goes hand in hand with an increase in VKT, as cars will have to relocate for parking purposes; the increase in VKT will be particularly pronounced if car-sharing is scarce and vehicles are thus idle while relocating.

ACES are expected to allow for a significant reduction in the amount of space dedicated to parking in urban areas (Anderson et al., 2014; Begg, 2014). Ambühl et al. (2016) expect that $12 \%$ of road space can be assigned to alternative usage forms due to lower demand for parking following the introduction of autonomous vehicles. According to ITF (2015), with $100 \%$ AV penetration, only $6-16 \%$ of 2015 parking needs remain. However, at a $50 \%$ ACES penetration only minor reductions in parking (to $3 / 4$ of current parking space requirements), or even an increase in required parking space is possible.

Reducing the space required for parking could have ramifications to the urban structure by affecting housing costs and productivity. Due to building regulations, currently the construction of new buildings often requires a compulsory provision of a minimum number of parking spaces, rendering housing substantially more expensive (up to $25 \%$ for a unit with two parking spaces, see Litman, 2016). The reduction of parking spaces in inner cities provides the possibility to increase urban density which would allow productivity gains from an increase in agglomeration benefits (e,g., Dericks and Koster, 2018). Cities could benefit from increased property tax revenues when unproductive parking spaces are replaced with taxable economic activities such as housing and retail spaces. Idle parking spaces can also be greened, potentially leading to a reduction in urban heat and as a result positive health effects (Onishi, 2010). 
While city centers might become denser (also because of the availability of affordable, convenient transport in the form of ACES, see Bischoff and Maciejewski, 2016) it could still be that ACES contribute to a reduction in urban density on the fringes of the city as a reduction in the value of travel time might lead to longer commutes and thereby an increase in urban sprawl. Thakur et al. (2016) simulate that Melbourne suburbs that are further than $30 \mathrm{~km}$ from the central business district might increase by $2-4 \%$ in population due to vehicle automation.

\section{Public finance in the advent of ACES}

Figure 4 summarizes the relationship between public finance and ACES, emphasizing that the relationship between these two components is not only a direct one, but also an indirect one that goes via the industry that produces and provides ACES as well as consumers, i.e. users of ACES (via their mobility behavior). Indirect, potentially large effects on public finance might also originate from productivity gains in firms described in Section 3.2.

Figure 4 - Public finance and ACES

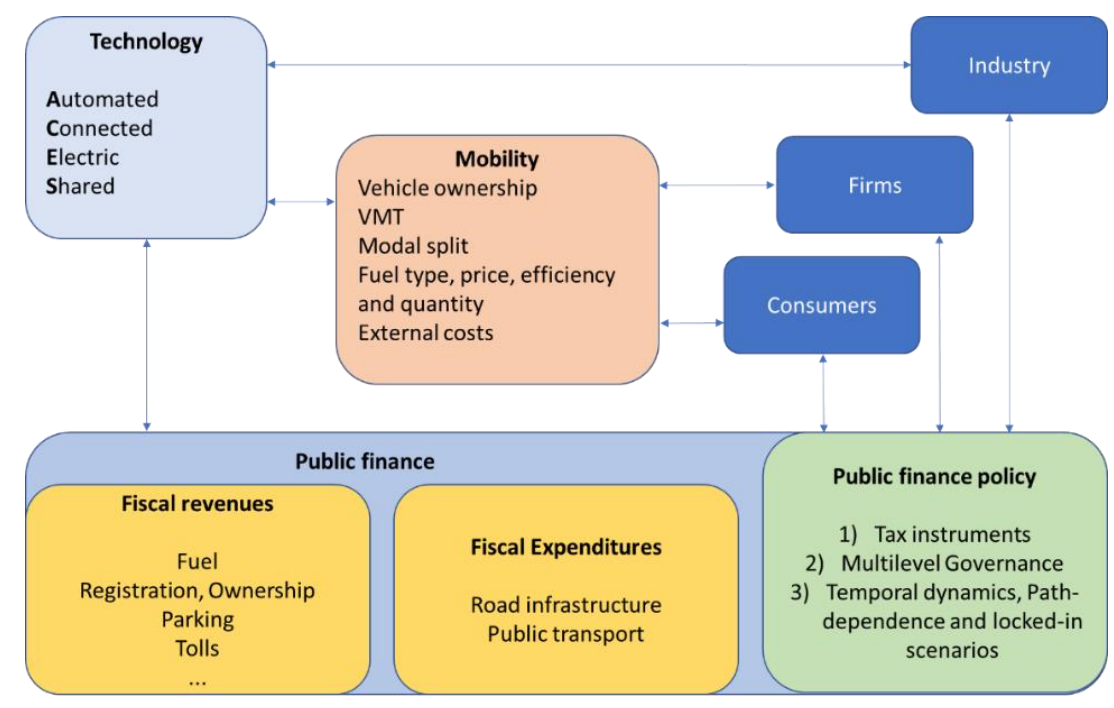

In this section, we formulate multiple hypotheses regarding public finance policies associated with ACES and bring forward arguments that support them. We also provide suggestions for future research. Our main hypothesis is that:

[H] The full socioeconomic benefits of ACES cannot be realized unless tailored public finance policies are implemented.

More specifically, we hypothesize that

[H1] ACES will render the introduction of (differentiated) road tolls more attractive.

[H2] ACES will shift decision making power concerning transport policies towards local (in particular urban) governments. 
[H3] Near-term public finance policy action regarding ACES is required in order to avoid lock-in effects in sub-optimal outcomes.

These three hypotheses will be outlined in more detail below:

\section{1. [H1] Differentiated road tolls}

As discussed in Section 3.3., there is extensive evidence that without additional charges, congestion levels in urban areas may increase substantially when the penetration rate of ACES increases (Smith 2012; Kaddoura and Bischoff, 2017; Adler, 2017; Pernestål Brenden and Kristoffersson, 2018). We argue that the likely increase in vehicle kilometers traveled (VKT) (and associated consequences, such as increased urban sprawl) can be countered efficiently by using (differentiated) road tolls (Smith 2012; Adler, 2017, Adler et al., 2017; Bloomberg Philantropies, 2017 make similar arguments).

Road tolls have been advocated for decades, starting with Vickrey's seminal paper (1969), with the aim of internalizing the externalities resulting from transportation. Due to road tolls being usage-dependent, they are more effective in reducing environmental and congestion externalities than registration and circulation taxes, especially if they are differentiated in time and space (Langer et al., 2017; Vanrykel et al., 2018). Road tolls also tend to be a better instrument for raising revenue than fuel taxes because travel is less elastic than fuel consumption (Parry and Small, 2005). Moreover, there is the possibility of a 'double benefit' and 'virtuous circle' depending on the use of revenue (Small, 2005).

However, road tolls have been successfully introduced in a few cities only (among others, in Singapore, London, Stockholm) and few road stretches (e.g., toll lanes in the US) so far. Most of the existing road toll implementations have high transaction costs, are second- or third-best, and lack public acceptance. The latter is especially true before their introduction (as opposed to after the introduction), when congestion is not considered a sizable problem by citizens, and when the use of the toll revenues is unclear and not earmarked for transport-related purposes (see De Borger and Proost, 2012).

With the advent of ACES, the problems associated with the current tolling schemes are likely to be substantially reduced. Lower transaction costs can be achieved from advancements in software and digitalization (e.g. ubiquitous GPS tracking of ACES and a close to $100 \%$ smartphone penetration rate). ${ }^{28}$ The same technologies allow for new, more targeted tax instruments with high flexibility that can be designed with the aim of limiting the presence of negative externalities (see Section 3.3), and allowing for a system-wide tax scheme rather than a tax scheme applied to selected road (stretches), which in turn limits spillover effects (i.e., traffic from tolled (main) roads being shifted to untolled (local) roads) (Eliasson, 2014; Calthrop and Proost, 1998; Ostrovsky and Schwarz, 2018). The tolls can, for instance, be set such that they take into account trip length, time of day, vehicle type (or even the occupancy rate) as well as the type of roads used along the trip (see also Hörl et al., 2016). Providers may then offer clients to choose between algorithms that select between cheaper and faster routes (Ostrovsky and Schwarz, 2018).

Also, a higher degree of acceptance of future road pricing schemes with ACES (compared to current and past road pricing schemes), and in turn a higher political viability seems achievable. A main reason is that with shared

\footnotetext{
28 " [...] theory of optimal tax systems [...] embraces the insights of optimal taxation but also considers the technology of raising
} taxes and the constraints placed upon tax policy by that technology" (Slemrod, 1989). 
ownership, the tolls may be directly charged to the individual traveler (and voter), but to the mobility service providers and/or fleet owners of ACES (Hensher, 2018). Depending on the market structure and demand elasticity these service providers will then impose these costs partially or fully on the consumers. Alternatively, even if road charges are directly charged to the consumer, the toll collection will be very convenient to users, as GPS-tracking of vehicles will avoid the necessity for toll booths. Another argument brought forward by Ostrovsky and Schwarz (2018), is that, unlike in the Vickrey bottleneck model where the individual drivers are equally well off after introducing a time-differentiated road toll (before they encountered the same cost by waiting in the queue), they are better off in a scenario with ride-sharing: without tolls each driver pays the entire cost in terms of waiting time; with tolls and if the ride is shared with at least another person, they pay less than half of the costs associated with the untolled equilibrium. Moreover, citizens can probably be convinced that fuel tax revenues need to be replaced by other tax revenues when fleet electrification proceeds, at least as long as the average cost of travel is still lower than or equal to the costs associated with the pre-ACES era.

Besides steering motives, revenue motives can also be highly relevant for the implementation of tolling schemes, as revenues from other vehicle-related tax bases (fuel, registration, circulation taxes) will decrease (as discussed in Section 3). The potential tax base for road tolls is large, while it is fairly small for registration and circulation taxes (in particular if car- and ride-sharing become more common). Earmarking the toll revenues for transport purposes will be beneficial for acceptance reasons (and can be justified with required infrastructure investments for ACES); however, (at least part of) the road toll revenues might also be transferred to the general budget of the tax levying governance body for financing other public expenses (similarly, to the current use of fuel taxes revenues, in particular in European countries).

Clearly, measures on the supply side (e.g., restricting the number of ACES) are also possible in order to avoid an increase in negative externalities, in particular from increased road congestion. Besides not being optimal from a welfare perspective, it is questionable whether they can be sustained in the long-run, if citizens and fleet providers lobby for better access to ACES. While restrictions in the number of ACES within a specific area do not create fiscal revenues per se, the licenses to operate ACES (at the level of the fleet provider or at the per-car level) could be taxed or auctioned by governmental bodies.

Future research:

Future research should focus on how such differentiated road tolls can be designed in an optimal way, taking into account both steering and revenue considerations, as well as the potential negative effect on ACES uptake and innovation, distributional concerns concerning disposable income and accessibility. Effects on related markets (in particular, the labor market and land use) and potential long-run dynamics need to be considered as well. The optimal tolling schemes will also depend strongly on local characteristics such as the city structure (e.g., Hirte and Tscharaktschiew, 2014), institutional and legal settings, the availability and quality of mode alternatives and the market structure of ACES providers (publicly vs. privately owned; competition vs. monopoly). These interactions, which so far have received only little attention in studies focused on deriving optimal road tolls, should be accounted for in future studies.

\section{2. [H2] Federal taxes and local primacy}

With the advent of ACES, both local as well as national bodies will have a strong incentive to implement road tolls, for revenue as well as steering reasons, as outlined in the previous section. National bodies are likely to be relatively 
more focused on revenue motives, as vehicle-related tax revenues (most of which are currently collected at the federal level, see Section 2.1) are expected to decrease substantially with the advent of ACES (as argued in Section 3). Local bodies (in particular cities) are likely to face negative externalities of ACES (in particular congestion), which naturally should make them relatively more focused on steering motives.

Federal governments will likely have to counterbalance the forgone tax revenues due to the introduction of ACES, unless strong macroeconomic benefits materialize from ACES as well as from automated freight transport, generating additional tax revenues from private and corporate incomes and consumption (see Section 3.2), or if expenditures (in infrastructure or other spending categories) can be decreased substantially. Both the macroeconomic gains as well as the decrease in expenditures are likely to materialize only in the long run, whereas the decrease in tax revenues is likely to materialize earlier, creating at least a temporary shortfall in revenues.

As described in the previous section, the primary and most obvious possibility to generate additional tax revenues are road tolls. However, other alternatives such as a moderate raise in tax rates that typically have a large base (income tax, corporate income tax, consumption taxes, etc.), or the introduction of a robot tax are also feasible. Higher taxes on electricity as a replacement for the lost fuel tax revenues are a rather weak alternative (currently, in OECD countries, they amount to 87 Euro per ton of $\mathrm{CO} 2$ from gasoline but only 5 euro per ton of $\mathrm{CO} 2$ from electricity (coal and peat): OECD, 2013). The main reasons are the expected low acceptance level by private households as well as the industry, and the possibility for tax evasion by private generation of electricity (e.g., using solar panels). Furthermore, more specialized taxes that target ACES directly (e.g. on batteries) may lead to innovation hampering.

It is likely that in the future the dominance of the federal states in levying vehicle-related taxes will shrink. The main reason is that the differentiated charges described in the previous section will probably in many instances be implemented by local governments (in particular, cities) and the corresponding tax revenues will then be captured by these local governments, as it is the case with most currently existing urban tolling schemes (e.g., Milan, London, and virtually all parking schemes). ${ }^{29}$ Legally, cities are in charge of their own transport systems in most countries (although the relevant legal settings differ widely), and the local context is known to local policy makers, which renders targeted pricing of externalities easier. Finally, cities do not only have steering but also revenue motives, as they will need a replacement for parking charges and traffic fines.

Cities are likely to also enjoy a first mover advantage compared to federal states, as dense high-income cities with a well-established car base and problems with air pollution are expected to encounter ACES diffusion prior to other areas (Kaas et al., 2016; RCCAO; 2016). This technological leadership may go hand in hand with more regulatory power: cities might require ACES fleet operators to tender for or buy licenses for their cars, fulfill specific safety and environmental standards, or have ACES in public ownership. ${ }^{30}$

Substantial inter-jurisdictional competition between local or regional public decision-makers may emerge. National bodies will mostly focus on the taxation of traffic on national roads (mostly highways and other main roads of national interest), while local (in particular urban) governance bodies will focus on the taxation of the secondary road network. As a substantial share of national roads (typically those with much traffic) tend to be located within city boundaries, legal disputes may arise about who is able to determine the level of the road toll, and even more

\footnotetext{
${ }^{29}$ The local implementation of tolls is in line with benefit principle, which states that those who use a service should pay for the resulting costs (Lindahl, 1919; Musgrave et al., 1987) as well as in line with a general trend of transferring fiscal responsibility to local governments (see for instance, Goldman and Wachs, 2003).

30 In a comparable case, some cities require car-sharing providers to operate (exclusively) electric cars.
} 
importantly, who is the recipient of tax revenues. Multiple tax systems based on different technologies are usually undesirable due to transaction costs; however, revenue sharing may be an option. Similar issues arise at a supranational level, including freight transport. For instance, regarding registration taxes (and the corresponding VAT and excise taxes) as well as circulation taxes, tax competition, and potentially a race to the bottom in tax rates, may emerge: national governments have an incentive to lower their taxes rates in order for fleet operators to register their car fleet in their country (Clark et al., 2017). In countries where registration taxes are levied at the regional or local level, this competition may take place even within jurisdictional units located in the same country (Vanrykel et al., 2018).

Overall, at the federal level, the share of vehicle-related taxes is likely to decrease, and in turn their steering power is likely to diminish. Cities are then likely to replace national or regional levels as the most relevant segmentation dimension that determines mobility behavior in terms of speed and scope (Kaas et al., 2016). A future with high penetration rates of ACES may thus entail higher vehicle-related tax revenues for local level of governance (in particular cities), and lower vehicle-related tax revenues for higher governance levels (in particular, the federal state). We do not expect such a pronounced shift on the expenditure side. As a result, we expect ACES to further deepen inequalities between cities and rural areas in terms of access to affordable mobility, as well as steering power increasingly being shifted to local (urban) level of governance.

\section{Future research:}

Game theory and political economy approaches may be useful for analyzing the interplay between local, regional and federal level of governance in the light of the introduction of ACES and the corresponding effects on fiscal revenues and expenditures at these different levels of governance. General equilibrium models and input-output analyses will be useful to predict the economic effects of different fiscal policies regarding ACES. The expected variation in benefits and costs of ACES between rural-urban regions but also along socio-economic variables is of high policy relevance.

\section{3. [H3] Path dependencies and lock-in effects}

Path-dependencies in policy are common for large political decisions that are based on a number of smaller contingent events for which timing and sequence matter (Pierson, 2000). They often (but not necessarily) lead to suboptimal equilibria, which are - sometimes prohibitively - costly to rectify, resulting in lock-in effects (Fisher, 1983; Pierson, 2000, Dixit, 1998).

Path-dependencies and lock-in effects in suboptimal equilibria also play a substantial role in public finance (Kato, 2003), including the transport domain. ${ }^{31}$ A prominent example is the tax rate imposed on diesel, which is lower than the tax imposed on petrol in many European countries, mainly due to lobby efforts by the logistics and the agricultural sector (Transport \& Environment, 2015). The resulting larger share of Diesel cars in these countries and their higher PMx emissions compared to petrol-based cars led to substantial air quality problems in urban areas. The "Diesel bonus" is still in place in most countries despite recurrent discussions driven by air quality problems (in line with the predictions of Hammar et al., 2004): policy makers face pressure from the public (a sizable share of

\footnotetext{
${ }^{31}$ An illustrative example concerns shipping: a tax exemption for fuel used for inland shipping along the entire Rhine river, has been signed in 1831 (Mannheim Act); to this date the taxation of fuel along the Rhine depends on whether the fuel is used for water or road transport (CCNR, 2018).
} 
population lives in households that own Diesel-driven cars) and lobbyism by car manufacturers (which invested heavily in the Diesel technology), the logistics and the agricultural cities (both of which use Diesel-based vehicles. ${ }^{32}$

In the context of ACES and public finance implications, path dependencies and lock-in effects are potentially highly relevant. An important area where inefficiencies due to path dependence may occur, concern ownership structures: fleet owners may potentially become very influential and gain market power in many regions (possibly even leading to a deterioration of alternative transport modes) in particular due to the presence of economies of scale. This can (partially) be avoided by establishing regulations that actively encourage competition, which has recently happened in other network- and platform-based industries: energy, telecommunication, insurance, and banking are prime examples, where regulations have been introduced that shall decrease the consumers' switching costs between providers and increase price transparency between providers. Market power of single fleet providers can also be limited by requiring them to participate in public tenders (with specified requirements concerning pricing and service levels). If this regulation comes too late, the market dominance by one or few providers might be very hard to combat and regulate, as evident from other platform-based business models: Google, Facebook, Amazon, Apple, AirBnB, and from the transport sector, most famously, Uber, which used their first mover advantage to set new behavioral norms (Kenney and Zysman, 2016). This is especially true if the regulation (potentially) leads to price increases for consumers, and hence lacks public support.

Another important aspect is that fiscal policies can have an ambiguous effect on innovation. If innovations are taxed too much and too early, their roll-out will be slowed down. If they are not taxed enough or even subsidized, tax advantages might be difficult to abolish when the penetration rate of the new technology has gained a significant market share, due to a lack of public acceptance. Subsidies might also promote inequalities, if for instance they subsidize the purchase of luxury brand EVs.

Overall, the transition period towards ACES might be costly in terms of foregone taxes (at least temporarily) and lock-in effects regarding sub-optimal subsidies.

Future research:

In order to identify risks of lock-in effects, transition paths for fiscal policies should be designed and evaluated. In line with the citizens' preference for "predictable institutions" (Teknologiradet, 2017), fiscal measures should be transparent, predictable and easy to understand (e.g. sudden price shocks should be avoided). Nevertheless, a fast developing and spreading technology as ACES is likely to require dynamic policy adaptation, an area of research that has so far not been very evident in transport economics but has been widely researched in environmental economics (e.g. Fischer et al, 2003).

\section{Conclusions and policy implications}

The advent of ACES is expected to have disruptive impacts on mobility and society as a whole. In this paper, we discuss potential implications of these new technologies on fiscal revenues and expenditures. Given that in most OECD countries a considerable share of (federal) tax revenues is composed of vehicle-related taxes (5-10\%), as well

32 The public debate is often referred to as "expropriation of Diesel car owners" in the public discussion, e.g. for the case of Germany (e.g. Reuters, 2018). 
as the expectation that ACES will require large infrastructure investments and may strongly affect public transport provision as well as labor market outcomes, it is likely that both fiscal revenues and expenditures will be substantially affected by the advent of ACES.

Clearly, as it is generally the case with disruptive technologies, future scenarios are surrounded with uncertainty concerning technological developments, uptake by the public, or industry structure. Even though technological development will likely take place at the global level, the uptake and industry structure might be local, and influenced by local preferences, institutional settings and the availability and quality of alternative modes (to mention just a few factors). Despite the inherent uncertainty concerning the future, we argue that policy makers should be aware of upcoming public finance challenges and take them into account in their current and near-term decision making. For this reason, we mapped out the status quo of the relationships between public finance and (passenger) transport, summarized the likely fiscal implications of ACES under a laissez faire approach, and came up with hypotheses and a research agenda concerning active public finance policy in the advent of ACES.

Much of the recent mobility literature, frequently motivated by technological aspects (and often under the header of "smart mobility"), is dominated by the view that ACES will predominantly have positive effects: through the conservation of fossil fuels (if electricity for EVs is sourced from renewables), by providing benefits to people who are currently unable to engage in independent mobility, the improved possibility for using travel time productively, an overall increase in transport efficiency, decrease in travel time, and the freeing up of public parking spaces. In this paper we argue that these positive effects may materialize in the medium to long term if ACES are a well-managed in terms of public policy. Conversely, almost none of the benefits might accrue (not even in the long term) if the process is not well managed, due to path-dependencies with suboptimal outcomes in terms of forgone tax revenue and high costs for the public sector. Specifically, we argue that the advent of ACES will require, but at the same time enable (differentiated) road tolling at a wider scale. We also argue that ACES will lead to disruptions in the fiscal revenues and expenditures that accrue to federal and local governments, likely shifting more power in transport policy making to the local (urban) level of governance. Third, we argue that path dependencies are strong in transport policy making, potentially leading to suboptimal fiscal policies that are hard to re-adjust in the future. This motivates our three main guidelines for policy making at the intersection of public finance and ACES:

First, ACES-related fiscal policies should be designed such that they are understandable, predictable and transparent, which are essential determinants of the acceptability of new tax schemes.

Second, ACES-related fiscal policies should take into account effects on related markets (especially those in which market distortions are present, such as the labor market), in order to avoid unintended consequences, which might not easily be reversible due to path-dependencies and lock-in effects. For instance, the automation of labor in the transport sector is predicted to be larger than the absorption capacity on the demand side (OECD), potentially followed by substantial distributional implications. (Some) tax revenues from the taxation of ACES might thus be earmarked towards skill upgrading for workers who are negatively affected by the disruptions in the transport sector. Taxes on ACES may moreover have a negative effect on innovation in the transport sector (Edquist et al., 1997), which might be counteracted by using parts of the government revenues from the taxation of mobility to finance innovation in ACES and related technologies (Mazzucato, 2015).

Third, near-term action is vital. The transition period might be costly in terms of foregone transport taxes, and suboptimal allocation of infrastructure and transport subsidies (public transport, tax reductions on company cars and electric vehicles) as well as high negative externalities. These possibilities should be anticipated in the near term in 
order to prevent such scenarios to the extent possible. Moreover, it might take some time for policy makers to test alternative instruments, possibly at a smaller scale, before being scaled up.

It is important to emphasize that many of our arguments also apply to the freight transport sector, however, more specific research is required to better understand how public finance related to freight transport will be affected by the advent of autonomous, electric trucks. Further suggestions for research on ACES and public finance implications, in particular regarding theoretical and simulation-based approaches, have been outlined in Section 4 of this paper. 


\section{References}

ACEA - European Automobile Manufacturers' Association (2013). Tax Guide 2013. http://www.acea.be/uploads/publications/20130326_TaxGuide2013Highlights.pdf.

ACEA - European Automobile Manufacturers' Association (2015). Tax Guide 2015. https://www.vda.de/dam/vda/publications/2015/ACEA-TAX-GUIDE_2015/ACEA\%20TAX\%20GUIDE_ 2015.pdf.

ACEA - European Automobile Manufacturers' Association (2017). Tax Guide 2017. http://www.acea.be/uploads/news_documents/ACEA_Tax_Guide_2017.pdf.

ACEA - European Automobile Manufacturers' Association (2018). ACEA Pocket Guide 2018-2019. http://www.acea.be/publications/article/acea-pocket-guide.

Adler (2017). To prevent autonomous vehicles clogging our cities, we need to talk about road-pricing. http://www.citymetric.com/transport/prevent-autonomous-vehicles-clogging-our-cities-we-need-talkabout-road-pricing-3050.

Adler, M. W. and van Ommeren, J. N. (2016). Does public transit reduce car travel externalities? Quasi-natural experiments' evidence from transit strikes. Journal of Urban Economics, 92, 106-119.

Adler, M. W., Liberini, F., Russo, A., and van Ommeren, J. N. (2017). Road Congestion and Public Transit. ITEA Conference Working Paper.

Adler, M. W., Pasidis, I., Levkovich, O. and Lembcke, A. C. (2018). Roads, market access and regional economic development. OECD Publishing.

Ahmad, E., and Brosio, G. (Eds.). (2015). Handbook of multilevel finance. Edward Elgar Publishing.

Alonso Raposo et al. (2018). An analysis of possible socio-economic effects of a Cooperative, Connected and Automated Mobility (CCAM) in Europe. European Commission Joint Research Center.

Ambühl, L., Ciari, F., and Menendez, M. (2016). What about space?: A simulation based assessment of AVs impact on road space in urban areas. In 16th Swiss Transport Research Conference (STRC 2016). Swiss Transport Research Conference (STRC).

Anderson, M. L. (2014). Subways, strikes and slowdowns: the impacts of public transit on traffic congestion. American Economic Review, 104(9), 2763-2796.

Antón-Sarabia, A., and Hernández-Trillo, F. (2014). Optimal gasoline tax in developing, oil-producing countries: The case of Mexico. Energy Policy, 67, 564-571.

Arnott, R., and Rowse, J. (1999). Modeling parking. Journal of Urban Economics, 45(1), 97-124.

Atherton, K. D. (2017). MIT study shows Manhattan only need 3,000 taxis. With efficient carpooling, the Big Apple could get by with a third of its current fleet. Popular Science. https://www.popsci.com/mit-study-showsmanhattan-only-needs-3000-taxis.

Bansal, P., Kockelman, K. M., and Singh, A. (2016). Assessing public opinions of and interest in new vehicle technologies: An Austin perspective. Transportation Research Part C: Emerging Technologies, 67, 1-14.

Begg, D. (2014). A 2050 Vision for London: what are the implications of driverless transport. London: Clear Channel.

Bertoncello, M. and D. Wee (2015). Ten ways autonomous driving could redefine the automotive world. McKinsey and Company.

Bischoff, J., and Maciejewski, M. (2016). Autonomous taxicabs in Berlin-a spatiotemporal analysis of service performance. Transportation Research Procedia, 19, 176-186.

Bjertnæs, G. H. (2017). The efficient combination of taxes on fuel and vehicles. https://brage.bibsys.no/xmlui/bitstream/handle/11250/2477055/DP867_web.pdf?sequence=3.

Bloomberg (2017). Electric vehicle outlook - Executive Summary.

Bloomberg Philantropies. (2017). Taming the autonomous vehicle. A Primer for Cities. Bloomberg Philantropies and Aspen Institute.

Brons, M., Nijkamp, P., Pels, E., and Rietveld, P. (2008). A meta-analysis of the price elasticity of gasoline demand. A SUR approach. Energy Economics, 30(5), 2105-2122.

Brown, A., Gonder, J., and Repac, B. (2013). An Analysis of Possible Energy Impacts. In G. Meyer, and S. Beiker, Road Vehicle Automation (pp. 137-153). Berlin: Springer. 
BFS - Bundesamt für Statistik (2017). Kosten und Finanzierung des Verkehrs Strasse und Schiene 2014. https://www.bfs.admin.ch/bfs/de/home/statistiken/mobilitaet-verkehr/kosten-finanzierung/strasselangsamverkehr.assetdetail.3482330.html.

Burgstaller, S., Flowers, D., Tamberrino, D., Terry, H. P., Yang, Y. et al. (2017). Rethinking Mobility. The pay-as-yougo car: Ride hailing just the start. Venture Capital Horizons. Goldman Sachs.

Calthrop, E., and Proost, S. (1998). Road transport externalities. Environmental and Resource Economics, 11(3-4), 335.

Calvert, S. C., Schakel, W. J., and van Lint, J. W. C. (2017). Will automated vehicles negatively impact traffic flow?. Journal of Advanced Transportation, 2017.

Cambridge Systematics, Mercator Advisors, Pisarski, A. E., and Wachs, M. (2012). Future financing options to meet highway and transit needs. Contractor's final report for NCHRP project 20-24(49), National Cooperative Highway Research Program, Transportation Research Board, Washington, DC.

CBinsight (2017). Big Auto's Tech Arms Race: The 5 Most active OEMs in Startup Investment and MandA. https://www.cbinsights.com/research/auto-oems-startup-investment-expert-intelligence/

CBS - Centraal Bureau voor de Statistiek (2014). Gemeenten verwachten 660 miljoen euro aan parkeerbelasting in 2014. https://www.cbs.nl/nl-nl/nieuws/2014/11/gemeenten-verwachten-660-miljoen-euro-aanparkeerbelasting-in-2014.

CBS - Centraal Bureau voor de Statistiek (2017). Provincies begroten 2,3 miljard voor verkeer en vervoer. https://www.cbs.nl/nl-nl/nieuws/2017/08/provincies-begroten-2-3-miljard-voor-verkeer-en-vervoer.

CCNR - Central Commission for the Navigation of the Rhine (2018). Legal basis. https://www.ccr-zkr.org/11020100en.html.

CEBR (2014). Economic and Environmental Costs of Gridlock: an assessment of the direct and indirect economic and environmental costs of idling during heavy road traffic congestion to households in the UK, France and Germany. London, UK.

Chen, T. D., Kockelman, K. M., and Hanna, J. P. (2016). Operations of a shared, autonomous, electric vehicle fleet: Implications of vehicle and charging infrastructure decisions. Transportation Research Part A: Policy and Practice, 94, 243-254.

Clark, B., Larco, N., and Mann, R. (2017). The Impacts of Autonomous Vehicles and E-Commerce on Local Government Budgeting and Finance. Urbanism Next, Sustainable Cities Initiative, University of Oregon. https://cpb-us-e1.wpmucdn.com/blogs.uoregon.edu/dist/f/13615/files/2017/07/Impacts-of-AVEcommerce-on-Local-Govt-Budget-and-Finance-SCI-08-2017-2n8wgfg.pdf.

Condliffe, J. (2017). Intelligent Machines. Why Some Autonomous Cars Are Going to Avoid the Internet. MIT Technology Review. https://www.technologyreview.com/s/603339/why-some-autonomous-cars-aregoing-to-avoid-the-internet

Congressional Budget Office. (2012). 'The budget and economic outlook: Fiscal years 2012 to $2022 . "$ Publication 4474, Washington, DC.

Cornet, A.; Mohr, D., Weig, F., Zerlin, B., Hein, A. P. (2012). Mobility of the future. Opportunities for automotive OEMs. McKinsey and Company.

David, P. A. (2001). Path dependence, its critics and the quest for 'historical economics'. Evolution and path dependence in economic ideas: Past and present, 15, 40.

Davidson, P., Spinoulas, A. (2015). Autonomous vehicles: what could this mean for the future of transport? In: Australian Institute of Traffic Planning and Management (AITPM) National Conference, Brisbane, Queensland.

De Borger, B., (2001). Discrete choice models and optimal two-part tariffs in the presence of externalities: optimal taxation of cars, Regional Science and Urban Economics 31, 471-504.

De Borger, B., and Mayeres, I. (2007). Optimal taxation of car ownership, car use and public transport: Insights derived from a discrete choice numerical optimization model. European Economic Review, 51(5), 11771204.

De Borger, B., and Proost, S. (2012). A political economy model of road pricing. Journal of Urban Economics, 71(1), 79-92.

De Hartog, J. J., Boogaard, H., Nijland, H., and Hoek, G. (2010). Do the health benefits of cycling outweigh the risks?. Environmental health perspectives, 118(8), 1109. 
Dericks, G. H., and Koster, H. R. (2018). The Billion Pound Drop: The Blitz and Agglomeration Economies in London (No. dp1542). Centre for Economic Performance, LSE.

Dijk, M., Wells, P., and Kemp, R. (2016). Will the momentum of the electric car last? Testing an hypothesis on disruptive innovation. Technological Forecasting and Social Change, 105, 77-88.

Dixit, A. K. (1998). The making of economic policy: a transaction-cost politics perspective. MIT press.

Duranton, G. and Turner, M. A. (2011). The Fundamental Law of Road Congestion: Evidence from US Cities. American Economic Review, 101 (6), pp. 2616-2652

Duranton, G., P. M. Morrow, and M. A. Turner, (2014). Roads and trade: Evidence from U.S. cities, Review of Economic Studies, 81(2), 681-724.

Ecenbarger, W. (2009). Buckle Up Your Seatbelt and Behave. www.smithsonianmag.com/science-nature/Presenceof-Mind-Buckle-Up-And-Behave.html.

Edquist, C. (1997 (Ed.) Systems of Innovation: Technologies, Institutions and Organizations, London, Routledge

Eliasson, J. (2014). Opportunities for transport financing through new technologies. Urban Access for the 21st Century: finance and governance models for transport infrastructure. Oxon/NewYork, Routledge, 118-145.

Elvik, R. (2000). How much do road accidents cost the national economy?. Accident Analysis and Prevention, 32(6), 849-851.

Eugensson, A., Brännström, M., Frasher, D., Rothoff, M., Solyom, S., and Robertsson, A. (2013). Environmental, safety legal and societal implications of autonomous driving systems. In Proceedings of the International Technical Conference on the Enhanced Safety of Vehicles (ESV). Seoul, South Korea.

European Commission (2002). Study on vehicle taxation in the member states of the European Union. https://ec.europa.eu/taxation_customs/sites/taxation/files/docs/body/vehicle_tax_study_15-022002.pdf.

European Commission (2011). Roadmap to a Single European Transport Area - Towards a competitive and resource efficient transport system. Communication on the Europe 2020 Flagship Initiative, and Innovation Union, C. O. $M$.

Eurostat (2018). Government revenue, expenditure and main aggregates. http://appsso.eurostat.ec.europa.eu/nui/show.do?dataset=gov_10a_main

Fagnant, D. J., and Kockelman, K. (2015). Preparing a nation for autonomous vehicles: opportunities, barriers and policy recommendations. Transportation Research Part A: Policy and Practice, 77, 167-181.

Fagnant, D. J., and Kockelman, K. M. (2014). The travel and environmental implications of shared autonomous vehicles, using agent-based model scenarios. Transportation Research Part C: Emerging Technologies, 40, 1-13.

Faria, R., Moura, P., Delgado, J., \& De Almeida, A. T. (2012). A sustainability assessment of electric vehicles as a personal mobility system. Energy Conversion and Management, 61, 19-30.

Fischer, C., Parry, I. W., and Pizer, W. A. (2003). Instrument choice for environmental protection when technological innovation is endogenous. Journal of environmental economics and management, 45(3), 523-545.

Fisher, F. M. (1983). The Disequilibrium Foundations of Equilibrium Economics, New York: Cambridge University Press.

Frey, C. B. and Osborne, M. A. (2017). The future of employment: How susceptible are jobs to computerisation. Technological Forecasting and Social Change, 114, pp. 254-280.

Frost and Sullivan (2016). Future of Carsharing Market to 2025. http://www.frost.com/sublib/displayreport.do?id=MB4D-01-00-00-00

Fullerton, D., and West, S. E. (2002). Can Taxes on Cars and on Gasoline Mimic an Unavailable Tax on Emissions. Journal of Environmental Economics and Management 43(1), 135-157

Fullerton, D., and West, S. E. (2010). Tax and Subsidy Combinations for the Control of Car Pollution, The B.E. Journal of Economic Analysis and Policy, 10 (1)

Fung, B. (2016), "How Driverless Cars Could Kill the Speeding Ticket-and Rob Your City." Washington Post, January 22. https://www.washingtonpost.com/news/the-switch/wp/2016/01/22/how-driverless-cars-could-killthe-speeding-ticket-and-rob-your-city/.

Fung, B. (2015). Driverless Cars Are Getting Into Accidents, But The Police Reports Are Not Being Made Public. Washington Post. http://wapo.st/1HbLHx9. 
Gawron, J. H., Keoleian, G. A., De Kleine, R. D., Wallington, T. J., Kin, H. C. (2018) Life Cycle Assessment of Connected and Automated Vehicles: Sensing and Computing Subsystem and Vehicle Level Effects, Environmental Science and Technology, 52, pp. 3249-3256.

Goldman, T., and Wachs, M. (2003). A quiet revolution in transportation finance: The rise of local option transportation taxes. University of California Transportation Center.

Gomez, J., and Vassallo, J. M. (2013). Comparative analysis of road financing approaches in Europe and the United States. Journal of Infrastructure Systems, 20(3), 04014008.

Greenblatt, J.B., and Shaheen, S. (2015). Automated vehicles, on-demand mobility, and environmental impacts. Curr Sustain 2(3), 74-81. http://link.springer.com/article/10.1007/s40518-015-0038-5.

Grigoratos, T. and Martini, G., (2014). Non-exhaust traffic related emissions. Brake and tyre wear PM: Literature review, European Commission Joint Research Centre (EU-JRC), Report EUR 26648 EN.

Guerra, E. (2016). Planning for cars that drive themselves: Metropolitan Planning Organizations, regional transportation plans, and autonomous vehicles. Journal of Planning Education and Research, 36(2), 210224.

Guerreiro, J., Rebelo, S. and Teles, P. (2017). Should Robots Be Taxed? Tech. rep., Centre for Economic Policy Research, London

Hammar, H., Löfgren, Å., and Sterner, T. (2004). Political economy obstacles to fuel taxation. The Energy Journal, 25(3), 1-17.

Harper, C. D., Hendrickson, C. T., Mangones, S., and Samaras, C. (2016). Estimating potential increases in travel with autonomous vehicles for the non-driving, elderly and people with travel-restrictive medical conditions. Transportation Research Part C: Emerging Technologies, 72, 1-9.

Hensher, D. A. (2018). Tackling road congestion-What might it look like in the future under a collaborative and connected mobility model?. Transport Policy, 66, A1-A8.

Hirte, G., and Tscharaktschiew, S. (2015). Optimal Fuel Taxes and Heterogeneity of Cities. Review of Regional Research, 35(2), 173-209.

Hörl, S., Ciari, F., and Axhausen, K. W. (2016). Recent perspectives on the impact of autonomous vehicles. Arbeitsberichte Verkehrs-und Raumplanung, 1216.

IHS Markit (2014). Self-Driving Cars Moving into the Industry's Driver's Seat. http://news.ihsmarkit.com/pressrelease/automotive/self-driving-cars-moving-industrys-drivers-seat.

INFRAS - Consultores em Transportes Inovação e Sistemas. (2002). Study on vehicle taxation in the member states of the European Union. European Commission.

ING (2017). Breakthrough of electric vehicles threatens European car industry. https://www.ing.nl/media/ing_ebz_breakthrough-of-electric-vehicle-threatens-european-carindustry_tcm162-128687.pdf.

Innes, R., (1996). Regulating Automobile Pollution under Certainty, Competition, and Imperfect Information, Journal of Environmental Economics and Management, 31, 219-239.

ITF - International Transport Forum (2017). Managing the Transition to Driverless Road Freight Transport: Case Specific Policy Analysis, International Transport Forum (ITF), Paris, France.

Jonas, A., S. C. Byrd, R. Shankar, and M. Ono. (2014) Nikola's Revenge: TESLA's New Path of Disruption. Morgan Stanley and Co., LLC.

Kaas, H. W. et al. (2016). Automotive revolution - perspective towards 2030. How the convergence of disruptive technology-driven trends could transform the auto industry. McKinsey and Company.

Kaddoura, I. \& Bischoff, J. (2017). Towards welfare optimal operation of shared autonomous vehicles. European Association of Research in Transportation (hEART) Conference 2017

Kageson, J. (2005). Reducing CO2 emissions from new cars. European Federation for Transport and Environment.

Karpilow, Q., and Winston, C. (2016). A New Route to Increasing Economic Growth: Reducing Highway Congestion with Autonomous Vehicles. Unpublished paper.

Kato, J. (2003). Regressive taxation and the welfare state: path dependence and policy diffusion. Cambridge University Press.

Kenney, M., \& Zysman, J. (2016). The rise of the platform economy. Issues in Science and Technology, 32(3), 61.

Kerry, C. and Karsten, J. (2017). Gauging investment in self-driving cars. Brookings Report. https://www.brookings.edu/research/gauging-investment-in-self-driving-cars/ 
KiM - Netherlands Institute for Transport Analysis (2015). Driver at the wheel? Self-driving vehicles and the traffic and transport system of the future. Dutch Ministry of Infrastructure and Environment.

Langer, A., Maheshri, V., \& Winston, C. (2017). From gallons to miles: A disaggregate analysis of automobile travel and externality taxes. Journal of Public Economics, 152, 34-46.

Leech, J., Hawes, M., Whelan, G., Scharring, K., and Bahiji, M. (2015). Connected and autonomous vehicles-the UK economic opportunity. KPMG.

Lin, P. (2013). The Ethics of Saving Lives With Autonomous Cars Are Far Murkier Than You Think. Wired. www.wired.com/opinion/2013/07/the-surprising-ethics-of-robot-cars.

Lindahl, E. (1919[1964]). Just Taxation - A Positive Solution. in Richard A. Musgrave and Alan T. Peacock (eds), Classics in the Theory of Public Finance, London: Macmillan, 168-76.

Link, H. and Kunert, U. (2017). Staatliche Einnahmen und Ausgaben im Verkehrssektor: Analyse der Datensituation und konzeptionelle Erfordernisse für eine Finanzierungsrechnung. Ökonomischer Vergleich der Verkehrsträger. https://www.umweltbundesamt.de/sites/default/files/medien/1410/publikationen/201712-20_texte_116-2017_oekonom_verkehr_teil1.pdf

Litman, T. (2014). Autonomous vehicle implementation predictions. Victoria Transport Policy Institute, 28.

Litman, T. (2015). Transit price elasticities and cross-elasticities. www.nctr.usf.edu/jpt/pdf/JPT 7-2 Litman.pdf.

Litman, T. (2016). Parking requirement impacts on housing affordability. Victoria Transport Policy Institute.

Litman, T., (2017). Autonomous Vehicle Implementation Predictions: Implications for Transport Planning. Victoria Transport Policy Institute.

Liu, J., Kockelman, K. M., Boesch, P. M., and Ciari, F. (2017). Tracking a system of shared autonomous vehicles across the Austin, Texas network using agent-based simulation. Transportation, 44(6), 1261-1278.

Maizlish, N., Woodcock, J., Co, S., Ostro, B., Fanai, A., and Fairley, D. (2013). Health cobenefits and transportationrelated reductions in greenhouse gas emissions in the San Francisco Bay area. American Journal of Public Health, 103(4), 703-709.

Mares, R., Stix, C., and Dewey, S. (2018). How Autonomous Vehicles Will Drive Our Budgets. An Analysis of the economic and fiscal impacts of self-driving cars on the Commonwealth of Massachusetts. Conservation Law Foundation (CLF). https://www.clf.org/wp-content/uploads/2018/07/CLF_AV_Report.pdf.

Martinez, L., and Crist, P. (2015). Urban Mobility System Upgrade-How shared self-driving cars could change city traffic. In International Transport Forum, Paris.

May, J. (2017). A Canadian town is paying Uber to give its citizens lifts because it can't be bothered to sort out a bus route. http://www.citymetric.com/transport/canadian-town-paying-uber-give-its-citizens-lifts-because-itcant-be-bothered-sort-out-bus.

Mazzucato, M., (2015). The Entrepreneurial State: Debunking Public vs. Private Sector Myths, Anthem Press, London

McKerracher, C. et al. (2016). An integrated perspective on the future of mobility. McKinsey and Company and Bloomberg New Energy Finance.

Michielsen, T., Gerlagh, R., van den Bijgaart, I., and Nijland, H. (2015). Fiscal policy and $\mathrm{CO} 2$ emissions of new passenger cars in the EU. CPB Netherlands Bureau for Economic Policy Analysis

Milakis, D., Snelder, M., van Arem, B., Homem de Almeida Correia, G., and van Wee, G. P. (2017a). Development and transport implications of automated vehicles in the Netherlands: scenarios for 2030 and 2050. European Journal of Transport and Infrastructure Research, 17(1).

Milakis, D., Snelder, M., Van Arem, B., Van Wee, B., and Correia, G. (2015). Development of automated vehicles in the Netherlands: scenarios for 2030 and 2050. Delft: Delft University of Technology.

Milakis, D., Van Arem, B., and Van Wee, B. (2017b). Policy and society related implications of automated driving: A review of literature and directions for future research. Journal of Intelligent Transportation Systems, 1-25.

Ministry of Infrastructure, Public Works and Water Management (2014). Rijksuitgaven aan vervoersinfrastructuur onveranderd op bijna 6 miljard euro. http://web.minienm.nl/mob2014/4_5.html. Dutch Ministry of Infrastructure and Environment.

Mohring, H. (1972). Optimization and Scale Economies in Urban Bus Transportation. American Economic Review, 62, 591-604.

Morgan Stanley Research (2017). Auto industry braces for electric shock. On the charge Report. https://www.morganstanley.com/ideas/electric-car-supply-chain.

Morris (2006). The fuel tax and alternatives for transportation funding. https://prism.ucalgary.ca/bitstream/handle/1880/44382/TransportPaper-Morris.pdf?sequence=1 
Muoio, D. (2017). Tesla owners are already getting insurance discounts for using Autopilot.

Musgrave, Richard A., Peggy B. Musgrave and Richard M. Bird (1987). Public Finance in Theory and Practice, 1st Canadian edition. McGraw-Hill Ryerson, Toronto.

Musick, N., and Petz, A. (2015). Public Spending on Transportation and Water Infrastructure, 1956 to 2014.

Naess-Schmidt, S. and Winiarczyk (2009). Company car taxation. Subsidies, welfare and environment. Copenhagen Economics for the report Curopean Commission. https://ec.europa.eu/taxation_customs/sites/taxation/files/docs/body/taxation_paper_22_en.pdf.

Nash, C. (2003). Unification of accounts and marginal costs for Transport Efficiency. https://trimis.ec.europa.eu/project/unification-accounts-and-marginal-costs-transport-efficiency\#tabdocs.

National Surface Transportation Infrastructure Financing Commission (NSTIFC). (2009). Paying our way: A new framework for transportation finance. Washington, DC.

Navigant Research (2016). Ford Sets a Date for Its Autonomous Vehicle Future. https://www.navigantresearch.com/tag/level-4-autonomy.

NHTSA - National Highway Traffic Safety Administration (2018). Automated vehicles for safety. https://www.nhtsa.gov/technology-innovation/automated-vehicles-safety.

NPR - National Public Radio (2015). Map: The Most Common* Job In Every State. https://www.npr.org/sections/money/2015/02/05/382664837/map-the-most-common-job-in-everystate.

Oberholzer-Gee, F., and Weck-Hannemann, H. (2002). Pricing road use: politico-economic and fairness considerations. Transportation Research Part D: Transport and Environment, 7(5), 357-371.

Odyssee-Mure (2015). Sectoral profile - Transport. Change in distance travelled by car. http://www.odysseemure.eu/publications/efficiency-by-sector/transport/distance-travelled-by-car.html.

OECD (2013). Taxing energy use: A graphical analysis. http://www.oecd.org/tax/tax-policy/taxingenergyuse.htm.

Oh, J. J., and Sinha, K. C. (2010). Self-financing and distance-based highway pricing scheme: State highway system perspective. Journal of Infrastructure Systems, 17(3), 95-106.

Ohnsman, A., (2014). Automated Cars May Boost Fuel Use, Toyota Scientist Says. Bloomberg Press. www.bloomberg.com/news/2014-07-16/automated-cars-may-boost-fuel-use-toyota-scientist-says.html.

Onishi, A., Cao, X., Ito, T., Shi, F., and Imura, H. (2010). Evaluating the potential for urban heat-island mitigation by greening parking lots. Urban forestry and Urban greening, 9(4), 323-332.

Ostermeijer, F., Koster, H. and Van Ommeren, J. N. (2018). Autonomous vehicles, residential parking prices and car demand. Eureka seminar. Department of Spatial Economics VU University Amsterdam.

Ostrovsky, M., and Schwarz, M. (2018). Carpooling and the Economics of Self-Driving Cars. Working paper. http://web.stanford.edu/ ost/papers/sdc.pdf

Parry, I. W., and Small, K. A. (2005). Does Britain or the United States have the right gasoline tax?. The American Economic Review, 95(4), 1276-1289.

Parry, I. W., and Small, K. A. (2009). Should urban transit subsidies be reduced? The American Economic Review, 99(3), 700-724.

Pernestål Brenden, A., and Kristoffersson, I. (2018). Effects of driverless vehicles: A review of simulations (No. 2018: 11). CTS-Centre for Transport Studies Stockholm (KTH and VTI).

Peterson, J., \& Lewis, R. (2017). Autonomous Vehicle Revenue Implications For Portland, Tigard, and Tualatin. https://scholarsbank.uoregon.edu/xmlui/handle/1794/23311.

Pierson, P. (2000). Increasing returns, path dependence, and the study of politics. American political science review, 94(2), 251-267.

Pigou, A. C. (1920). The economics of welfare. McMillan and Co., London.

Pinjari, A.R., B. Augustin, N. Menon. (2013). Highway Capacity Impacts of Autonomous Vehicles: An Assessment. Center for Urban Transportation Research (CUTR). University of South Florida. http://www.tampaxway.com/Portals/0/documents/Projects/AV/TAVI_8-CapacityPinjari.pdf.

Pinkse, J., Bohnsack, R., and Kolk, A. (2014). The Role of Public and Private Protection in Disruptive Innovation: The Automotive Industry and the Emergence of Low-Emission Vehicles. Journal of Product Innovation Management, 31(1), 43-60.

Pomerleau, K. (2015). How High are Other Nations' Gas Taxes?. Tax foundation. https://taxfoundation.org/howhigh-are-other-nations-gas-taxes/. 
Pratt, M., Macera, C.A., and Wang, G. (2000). Higher direct medical costs associated with physical inactivity. The Physician and Sportsmedicine 28 (10), 63-70.

Proost, S., Van Dender, K., Courcelle, C., De Borger, B., Peirson, J., Sharp, D., ... and Van den Bergh, J. C. J. M. (2002). How large is the gap between present and efficient transport prices in Europe?. Transport policy, 9(1), 4157.

Ranft, F., Adler, M. W., Diamond, P., Guerrero, E. and Laza, M. (2016). Freeing the road: Shaping the future for autonomous vehicles. Policy Network Publication.

RCCAO - Residential and Civil Construction Alliance of Ontario (2016). Ontario Must Prepare for Vehicle Automation: Automated vehicles can influence urban form, congestion and infrastructure delivery. http://rccao.com/research/files/RCCAO_Vehicle-Automation_OCT2016_WEB.pdf

Reuters (2018). Factbox: Wider impact of bans on diesel cars in German cities. https://www.reuters.com/article/usgermany-emissions-impact-factbox/factbox-wider-impact-of-bans-on-diesel-cars-in-german-citiesidUSKCN1GC1ZJ.

Rogers, E. M. (1995). Diffusion of Innovation. New York, The Free Press.

RVO - Dutch National Office for Enterprising (2013). Closer look at the development of electric vehicles in 2013 [in Dutch].

SAE International (2016). Taxonomy and Definitions for Terms Related to Driving Automation Systems for On-Road Motor Vehicles; https://saemobilus.sae.org/content/j3016_ 201609.

Saffo, P. and Bergbaum, A. (2013). “Are Completely Self-Driving Cars Feasible in the Foreseeable Future?" The Economist, 3 May 2013; at www.economist.com/debate/days/view/974.

Schiller, T., Scheidl, J., Pottebau, T., (2017). Car sharing in Europe. Business models, national variations and upcoming disruptions. Deloitte Monitor.

Schmidt, A., Reers, J. and Gerhardy, A. (2018). Mobility as a Service. Mapping a route towards future success in the automotive ecosystem. Accenture.

Schonberger, B. and Gutmann, S. (2013). A Self-Driving Future: At the Intersection of Driverless Cars and Car Sharing, Sightline Institute. http://daily.sightline.org/2013/06/04/a-self-driving-future.

Schuitema, G., and Steg, L. (2008). The role of revenue use in the acceptability of transport pricing policies. Transportation Research Part F: Traffic Psychology and Behaviour, 11(3), 221-231.

Shanker, R., Jonas, A., Devitt, S., Huberty, K., Flannery, S., Greene, W., ... and Moore, J. (2013). Autonomous cars: Self-driving the new auto industry paradigm. Morgan Stanley

Silberg, G., Wallace, R., Matuszak, G., Plessers, J., Brower, C., and Subramanian, D. (2012). Selfdriving cars: The next revolution. KPMG and Center for Automotive Research. KPMG: Center, for Automotive Research.

Sivak, M., and Schoettle, B. (2015). Road safety with self-driving vehicles: General limitations and road sharing with conventional vehicles.

Skinner, R. (2016). Making better places: autonomous vehicles and future opportunities.

Slemrod, J. (1989). Optimal taxation and optimal tax systems. National Bureau of Economic Research No. w3038.

Small, K. (2005). Road pricing and public transit: Unnoticed lessons from London. Access, 26(3), 10-15.

Small, K. A, and Verhoef, E. T. (2007). The economics of urban transportation. Routledge.

Smith, B. W. (2012), Managing Autonomous Transportation Demand, Santa Clara Law Review, Vol. 52, No 4, Article 8; at http://digitalcommons.law.scu.edu/lawreview/vol52/iss4/8.

Statline (2018). Gemeentebegrotingen; heffingen per gemente. https://opendata.cbs.nl/statline/\#/CBS/nl/dataset/83642NED/table?ts=1519377066586

Sterner, T. (2012). Distributional effects of taxing transport fuel. Energy Policy, 41, 75-83.

Tachet, R., Sagarra, O., Santi, P., Resta, G., Szell, M., Strogatz, S. H., and Ratti, C. (2017). Scaling law of urban ride sharing. Scientific reports, 7.

Teknologiradet (2017). This time its personal. The digital shift in the public sector. https://teknologiradet.no/wpcontent/uploads/sites/19/2013/08/Report_This-time-its-personal_The-digital-shift-in-the-publicsector.pdf.

Thakur, P., Kinghorn, R., and Grace, R. (2016). Urban form and function in the autonomous era. In Australasian Transport Research Forum (ATRF), 38th, 2016, Melbourne, Victoria, Australia.

The Economist. (2014). The cost of traffic jams. https://www.economist.com/the-economistexplains/2014/11/03/the-cost-of-traffic-jams.

The Economist. (2017). Roadkill. August 12. 
Thuemmel, U. (2018). Optimal Taxation of Robots. https://www.cesifogroup.de/dms/ifodoc/docs/Akad_Conf/CFP_CONF/CFP_CONF_2018/pse18-van-der-

Ploeg/Papers/pse18_Thuemmel.pdf. Working paper

Tietge, U., Mock, P., Lutsey, N., Campestrini, A. (2016). Comparison of Leading Electric Vehicle Policy and Deployment in Europe. Deutsche Gesellschaft fuer Internationale Zusammenarbeit (GIZ), Berlin. White Paper.

Transport \& Environment (2011). Q\&A: Funding for transport infrastructure in the new EU budget. Comments on the Commission's communication "A Budget for Europe 2020". https://www.transportenvironment.org/publications/funding-transport-infrastructure-new-eu-budget.

Transport \& Environment (2015). Europe's tax deals for diesel. https://www.transportenvironment.org/sites/te/files/publications/2015_10_Europes_tax_deals_for_dies el_FINAL.pdf

Tresch, R. W. (2014). Public finance: A normative theory. Academic Press.

Trommer, S. et al. (2016). Autonomous Driving. The Impact of Vehicle Automation on Mobility Behaviour. Institute of Transport Research. www.ifmo.de/tl_files/publications_content/2016/ifmo_2016_Autonomous_Driving_2035_en.pdf.

Tscharaktschiew, S. (2015). How much should gasoline be taxed when electric vehicles conquer the market? An analysis of the mismatch between efficient and existing gasoline taxes under emerging electric mobility. Transportation Research Part D: Transport and Environment, 39, 89-113.

Underwood, S. (2014). Automated, Connected, and Electric Vehicle Systems: Expert Forecast and Roadmap for Sustainable Transportation. Graham Institute for Sustainability, University of Michigan, Ann Arbor.

van Arem, B., Driel, C. J., and Visser, R. (2006). The Impact of Cooperative Adaptive Cruise Control on Traffic-Flow Characteristics. IEEE transactions on intelligent transportation systems, 7 (4), 429-436.

Van Ommeren, J. N., Wentink, D., and Rietveld, P. (2012). Empirical evidence on cruising for parking. Transportation Research Part A: Policy and Practice, 46(1), 123-130.

Vanrykel, F, De Borger, B., and Bourgeouis, M. (2018). Sharing cars: a legal and economic analysis of the taxation of B2C carsharing models. Unpublished working paper.

Vickrey, W. S. (1969). Congestion theory and transport investment. The American Economic Review, 59(2), 251-260. Volkskrant (2014). Seven tax breaks on electric cars cost Dutch treasury $€ 500 \mathrm{~m} .29$ March.

Wadud, Z.; Mackenzie, D.; Leiby, P. (2016). Help or hindrance? The travel, energy and carbon impacts of highly automated vehicles. Transportation Research Part A: Policy and Practice, 86, 1-18.

Wagner, J., Baker, T., Goodin, G., and Maddox, J. (2014). Policy Implications of Automated Vehicles on Texas Highways. Technical Report 600451-00029-1 (Vol. 7). College Station, Texas: Texas A\&M Transportation Institute.

Wakeley, H. L, Griffin, W. M., Hendrickson, C, and Matthews, H. S. (2008). "Alternative transportation fuels: Distribution infrastructure for hydrogen and ethanol in lowa." Journal of Infrastructure Systems, 10.1061/(ASCE) 1076-0342(2008)14:3(262), 262-271.

Walker, J. and Johnson, C. (2016). Peak Car Ownership: The Market Opportunity of Electric Automated Mobility Services. Rocky Mountain Institute, 2016. http://www.rmi.org/peak_car_ownership.

WHO (2017). Road traffic injuries. Fact Sheet. www.who.int/mediacentre/factsheets/fs358/en/.

Wijnen, W. and Stroeker, N. E. (2009). Uitgaven aan verkeersveiligheid. Een schatting voor 2007. Stichting Wetenschappelijk Onderzoek Verkeersveiligheid SWOV.

Zhou, Y., Wang, M., Hao, H., Johnson, L., and Wang, H. (2015). Plug-in electric vehicle market penetration and incentives: a global review. Mitigation and Adaptation Strategies for Global Change, 20(5), 777-795. 